\title{
VAPOR PRESSURE OF AMMONIA
}

\author{
By Carl S. Cragoe, Cyril H. Meyers, and Cyril S. Taylor
}

CONTENTS

I. Introduction.

Page

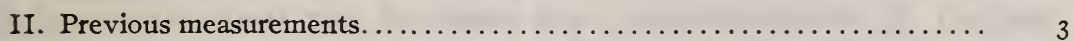

III. General description of apparatus and method .................. ro

IV. Purification of samples and description of manometer fillings........ I3

V. Description of preliminary experiments................. I4

I. Hysteresis in an impure sample..................... I4

2. Lag in coming to equilibrium ....................... I6

VI. Measurements by the static method .................... I9

VII. Determination of the normal boiling point by the dynamic method... . 26

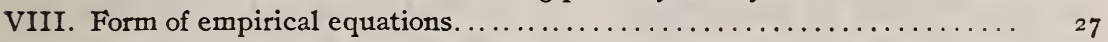

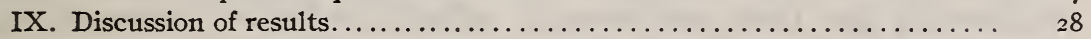

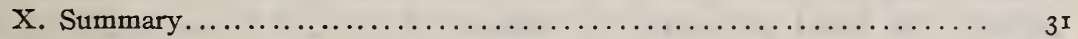

Appendixes:

I. Vapor pressure of ammonia (degrees centigrade, mm of mercury

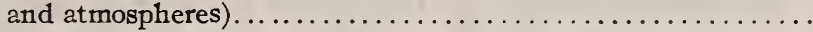

2. Vapor pressure of ammonia (degrees Fahrenheit, pounds per square inch and atmospheres)

3. Rate of change of vapor pressure with temperature $\left(\frac{d p}{d \theta}\right) \ldots \ldots$

\section{INTRODUCTION}

The measurements presented in this paper form a portion of the work undertaken by the Bureau of Standards in the determination of the thermal properties of materials used as refrigerating media. The existing data on the vapor-pressure-temperature relation for ammonia are undoubtedly sufficiently accurate to meet the requirements of refrigeration engineering. The Clapeyron equation, however, offers a means of correlating the measurements of the latent heat of vaporization (already published), ${ }^{1}$ with the data on specific volumes of saturated liquid and vapor (to be published shortly), provided the slope of the saturation line can be determined with sufficient accuracy. On account of the large errors which may be introduced into the calculated values of the 
slope by relatively small errors in the pressure or temperature, it appeared that existing data were deficient either in the range or the precision required.

The accuracy of any vapor-pressure measurements is determined, in general, by four factors; namely, (a) purity of the material, (b) certainty of equilibrium conditions, (c) precision of the pressure-measuring instrument, and $(d)$ temperature measurement and control.

(a) The extent to which factors $(a)$ and $(b)$ may affect the results of the vapor-pressure measurements will depend upon the methods used. Nonvolatile impurities present in solution would affect measurements by the static method, and also by the dynamic method, if measurements were made of the temperature of the boiling liquid, while their effect on the temperature of the condensing vapor is relatively unimportant. Noncondensing gases have but little effect on measurements by the dynamic method, while in the static method a small amount of noncondensing gas may affect the measured pressure to an extent out of all proportion to the amount of gas present. It is worthy of note that the noncondensing gas does not notably affect the vapor pressure, but causes the total pressure, as measured by the static method, to differ from the true vapor pressure.

(b) In measurements by the static method a very considerable lag in the attainment of equilibrium between the vapor and its liquid may be encountered even with a liquid well freed from impurities, especially if the liquid is not agitated. An example of this is furnished later. The presence of a small amount of permanent gas, such as air, greatly increases the lag in coming to pressure equilibrium. This was found to be the case at low temperatures, as illustrated in an attempt to measure the boiling point of a commercial sample of ammonia by the static method.

(c) The sensitivity of the pressure-measuring instruments used in the present work was such as to permit readings of pressure to I part in 5000, or better, except for pressures below I atmosphere. Pressures below 5 atmospheres were measured with mercury manometers; pressures between 5 and $\mathrm{I}_{5}$ atmospheres with a mercury manometer and with a piston gage; pressures above 15 atmospheres with a piston gage only.

(d) Temperature control plays an important rôle in any vaporpressure measurement, particularly in the establishing of equilibrium. A change in the temperature of $0.1^{\circ} \mathrm{C}$ in the case of 
ammonia is equivalent to a change in the vapor pressure of about $2 \mathrm{~mm}$, I $2 \mathrm{~mm}$, and $40 \mathrm{~mm}$ of mercury at $-50^{\circ}, \mathrm{O}^{\circ}$, and $+50^{\circ} \mathrm{C}$, respectively, or a percentage change in pressure of about $0.7,0.4$, and 0.25 , respectively. The aim in the present experiments was to maintain temperatures constant to o.or ${ }^{\circ} \mathrm{C}$, or better, for very long time intervals. Piatinum resistance thermometers were employed for the temperature measurements and temperatures were read to thousandths of a degree.

\section{PREVIOUS MEASUREMENTS}

The measurements of various observers are given in Table $\mathrm{I}$, which also includes for comparison, in the columns designated $p$ calc. the final results obtained in the present investigation. Various determinations of the normal boiling point of ammonia are given in Table 2 .

TABLE 1.-Previous Measurements of Vapor Pressure of Ammonia Compared with Fresent Results

\begin{tabular}{|c|c|c|c|c|c|c|c|c|}
\hline Temp. & pobs. & $\begin{array}{l}p \text { calc. } \\
\text { present } \\
\text { work }\end{array}$ & Temp. & $p$ obs. & $\begin{array}{l}p \text { calc. } \\
\text { present } \\
\text { work }\end{array}$ & Temp. & pobs. & $\begin{array}{l}p \text { calc. } \\
\text { present } \\
\text { work }\end{array}$ \\
\hline${ }^{\circ} \mathrm{C}$ & $\mathrm{mm}$ & $\mathrm{mm}$ & \multirow{2}{*}{\multicolumn{3}{|c|}{ Regnault (1862) }} & ${ }^{\circ} \mathrm{C}$ & $\mathrm{mm}$ & $\operatorname{mm}$ \\
\hline \multicolumn{3}{|c|}{ Bunsen (1839) } & & & & \multirow{2}{*}{\multicolumn{3}{|c|}{$\begin{array}{c}\text { Regnault (1862) } \\
\text { Second series }\end{array}$}} \\
\hline-33.7 & 749.3 & 746.6 & \multicolumn{3}{|c|}{ First series } & & & \\
\hline-5.0 & 3040.0 & 2661.5 & 0 & 3207.7 & 3221.0 & +6.93 & 4140.0 & 4143.0 \\
\hline 0 & 3610.0 & 3221.0 & 0 & 3212.7 & 3221.0 & +7.32 & 4199.7 & 4200.5 \\
\hline+5.0 & 4260.0 & 3868.0 & 0 & 3207.5 & 3221.0 & +7.34 & 4198.1 & 4204.0 \\
\hline+10.0 & 4980.0 & 4612.0 & 0 & 3214.7 & 3221.0 & +8.45 & 4368.9 & 4370.5 \\
\hline+15.0 & 5780.0 & 5462.5 & 0 & 3198.4 & 3221.0 & +11.42 & 4835.8 & 4842.5 \\
\hline+20.0 & 6670.0 & 6428.5 & -18.03 & 1524.9 & 1555.9 & +13.52 & 5335.3 & 5199.0 \\
\hline \multicolumn{3}{|c|}{ Faraday (1845) } & -16.79 & 1614.9 & 1641.8 & $\begin{array}{l}710.06 \\
+18.15\end{array}$ & 6134.9 & 6057.0 \\
\hline-17.78 & 1889.8 & 1572.9 & -16.58 & 1630.5 & 1656.7 & $\begin{array}{l}19.29 \\
+19.29\end{array}$ & 6399.1 & 6284.0 \\
\hline-12.61 & 2286.0 & 1959.6 & -13.09 & 1900.4 & 1920.8 & $\begin{array}{r}719.29 \\
+19.29\end{array}$ & 6382.7 & 6284.0 \\
\hline-7.78 & 2667.0 & 2385.3 & -12.15 & 1980.9 & 1997.3 & $\begin{array}{r}25.35 \\
+25\end{array}$ & 7676.3 & 7602.0 \\
\hline-6.11 & 2834.6 & 2548.3 & +3.97 & 3615.7 & 3727.0 & +32.70 & 9569.6 & 9473.0 \\
\hline-3.33 & 3078.5 & 2839.0 & +4.72 & 3812.1 & 3829.5 & \multirow{4}{*}{\multicolumn{3}{|c|}{$\begin{array}{l}\text { Regnault (1862) } \\
\text { Third series } \\
\text { Open manometer }\end{array}$}} \\
\hline 0 & 3383.3 & 3221.0 & \multirow{2}{*}{\multicolumn{3}{|c|}{$\begin{array}{l}\text { Regnault (1862) } \\
\text { Second series }\end{array}$}} & & & \\
\hline+0.56 & 3429.0 & 3288.5 & & & & & & \\
\hline+5.00 & 3886.2 & 3868.0 & -30.96 & 838.4 & 855.6 & & & \\
\hline+6.67 & 4084. 3 & 4105.5 & -31.37 & 823.6 & 838.5 & -25.70 & 1117.7 & 1100.7 \\
\hline+7.22 & 4152.9 & 4186.0 & -31.48 & 815.1 & 834.0 & -25.84 & 1097.2 & 1093.5 \\
\hline+9.44 & 4442.5 & 4523.5 & -27.36 & 1006.7 & 1017.9 & -23.92 & 1187.3 & 1195.4 \\
\hline+10.78 & 4572.0 & 4737.5 & -27.47 & 1002.9 & 1012.6 & -18.31 & 1518.7 & 1537.0 \\
\hline+11.11 & 4648.2 & 4791.5 & -22.71 & 1244.5 & 1263.3 & -18.10 & 1529.9 & 1551.1 \\
\hline+12.78 & 4861.6 & 5071.5 & -22.60 & 1251.7 & 1269.6 & -16.17 & 1670.0 & 1686.1 \\
\hline+13.61 & 4953.0 & 5215.0 & -18.37 & 1518.2 & 1533.0 & -13.51 & 1867.9 & 1887.3 \\
\hline+15.56 & 5257.8 & 5564.5 & -18.35 & 1513.5 & 1534.3 & -13.55 & 1859.9 & 1884.2 \\
\hline+16.28 & 5334.0 & 5698.5 & -10.42 & 2119.4 & 2144.4 & -9.21 & 2222.4 & 2252.3 \\
\hline+18.67 & 5715.0 & 6159.5 & -10.52 & 2133.8 & 2135.7 & -5.03 & 2599.6 & 2658.4 \\
\hline+19.44 & 5814.1 & 6314.5 & 0 & 3203.7 & 3221.0 & -0.10 & 3159.1 & 3208.8 \\
\hline+28.33 & 7620.0 & 8323.0 & 0 & 3206.7 & 3221.0 & +6.24 & 3963.7 & 4043.0 \\
\hline
\end{tabular}


TABLE 1-Continued

\begin{tabular}{|c|c|c|c|c|c|c|c|c|}
\hline Temp. & $p$ obs. & $\begin{array}{l}\text { p calc. } \\
\text { present } \\
\text { work }\end{array}$ & Temp. & pobs. & $\begin{array}{c}p \text { calc. } \\
\text { present } \\
\text { work }\end{array}$ & Temp. & $p$ obs. & $\begin{array}{l}\text { p calc. } \\
\text { present } \\
\text { work }\end{array}$ \\
\hline${ }^{\circ} \mathrm{C}$ & $\mathrm{mm}$ & $\mathrm{mm}$ & ${ }^{\circ} \mathrm{C}$ & $\mathrm{mm}$ & $\mathrm{mm}$ & & mm & $\mathbf{m m}$ \\
\hline \multicolumn{3}{|c|}{ Regnault (1862) } & \multicolumn{3}{|c|}{ Brill (1906) } & \multicolumn{3}{|c|}{ Burrell and Robertson (1915) } \\
\hline \multicolumn{3}{|c|}{ Third series } & -54.4 & 239.5 & 234.9 & -39.3 & 600.0 & 558.8 \\
\hline \multicolumn{3}{|c|}{ Closed manometer } & -50.7 & 309.3 & 294.1 & -37.7 & 650.0 & 608.0 \\
\hline+9.98 & 4550.4 & 4609.0 & -46.2 & 403.5 & 382.2 & -36.3 & 700.0 & 653.9 \\
\hline+14.38 & 5302.4 & 5351.0 & -45.0 & 437.1 & 409.1 & -35.4 & 730.0 & 684.9 \\
\hline+19.70 & 6318.0 & 6367.0 & -41.5 & 521.9 & 496.5 & -34.6 & 760.0 & 713.4 \\
\hline+30.49 & 8802.9 & 8877.0 & -39.8 & 568.2 & 544.1 & Keyes an & Brownlee & 1916) \\
\hline $\begin{array}{l}+38.90 \\
\end{array}$ & 11236.1 & 11306.0 & -38.2 & 610.4 & 592.3 & -33.22 & 750.8 & 764.8 \\
\hline+48.93 & 14670.0 & 14826.0 & -33.0 & 761.0 & 773.3 & 0 & 3255.5 & 3221.0 \\
\hline+55.47 & 17333.9 & 17529.0 & \multicolumn{3}{|c|}{ Davies (1906) } & +20 & 6480.4 & 6428.5 \\
\hline+64.35 & 21619.7 & 21770.0 & -49.8 & 298.0 & 310.2 & +25 & 7574.0 & 7520.5 \\
\hline+73.32 & 26766.4 & 26793.0 & -41.0 & 531.0 & 510.1 & +30 & 8808.0 & 8749.0 \\
\hline+81.72 & 32171.0 & 32238.0 & -30.0 & 867.0 & 896.7 & +35 & 10196.0 & 10124.0 \\
\hline \multicolumn{3}{|c|}{ Blümcke (1888) } & -20.0 & 1392.9 & 1426.8 & +40 & 11722.0 & 11658.0 \\
\hline-18.5 & 1451.6 & 1524.3 & -15.0 & 1726. 2 & 1772. 4 & +45 & 13429.0 & 13361.0 \\
\hline 0 & 3207.2 & 3221.0 & -10.0 & 2145.9 & 2181.4 & +50 & 15292.0 & 15245.0 \\
\hline+34.0 & 9728.0 & 9837.0 & -5.0 & 2616.9 & 2661.5 & +55 & 17393.0 & 17323.0 \\
\hline+63.5 & 21310.4 & 21334.0 & \multicolumn{3}{|c|}{ Holst (1915) } & +60 & 19641.0 & 19606.0 \\
\hline \multicolumn{3}{|c|}{ Brill (1906) } & -43.15 & 449.7 & 453.6 & +65 & 22187.0 & 22108.0 \\
\hline-80.0 & 35.2 & 37.6 & -37.35 & 614.4 & 619.1 & +70 & 24881.0 & .27842 .0 \\
\hline-79.0 & 38.0 & 40.8 & -32.57 & 784.6 & 790.1 & +75 & 27857.0 & 27822.0 \\
\hline-77.6 & 44.1 & 45.8 & +19.58 & 6295.1 & 6342.5 & +80 & 31102.0 & 31060.0 \\
\hline-75.1 & 51.8 & 55.7 & +45.05 & 13409.4 & 13379.0 & +85 & 34640.0 & 34573.0 \\
\hline-72.7 & 62.5 & 67.0 & \multicolumn{3}{|c|}{ Burrell and Robertson (1915) } & +90 & 38443.0 & 38375.0 \\
\hline-70.4 & 74.9 & 79.6 & -76.1 & 50.0 & 51.5 & +95 & 42524.0 & 42482.0 \\
\hline-68.3 & 87.5 & 92.7 & -66.6 & 100.0 & 104.7 & +100 & 46934.0 & 46910.0 \\
\hline-64.4 & 116.0 & 122.1 & -60.8 & 150.0 & 155.8 & +105 & 51769.0 & 51676.0 \\
\hline-62.8 & 136.0 & 136.2 & -56.8 & 200.0 & 202.0 & +110 & 56858.0 & 56799.0 \\
\hline-60.8 & 157.6 & 155.7 & -50.7 & 300.0 & 294.0 & +115 & 62364.0 & 62296.0 \\
\hline-59.5 & 172.4 & 169.6 & -46.3 & 400.0 & 380.1 & +120 & 68274.0 & 68187.0 \\
\hline-56.5 & 210.0 & 205.9 & -42.4 & 500.0 & 472.6 & +125 & 74708.0 & 74493.0 \\
\hline
\end{tabular}

The temperature control, particularly at the lower temperatures in some of the earlier measurements, was not sufficient to permit of accuracy. Therefore, the deviations in temperature of previous results from the present work are represented graphically in Fig. I. The percentage deviations of pressure are shown in Fig. 2. The four curves also shown in these figures represent the deviations of values computed by Regnault, ${ }^{2}$ Goodenough and Mosher, ${ }^{3}$ Holst, ${ }^{4}$ and Keyes and Brownlee. ${ }^{5}$

The earliest measurements were made by Bunsen ${ }^{6}$ in 1839 and Faraday ${ }^{7}$ in 1845 . Faraday expressed his results in atmospheres of 30 inches of mercury. Their results are more of historic in-

\footnotetext{
2 Mém. Inst. France, 26, p. 596; 1862.

${ }^{3}$ Univ. of Ill. Exp. Station, Bull. 66; 1913.

b. Am. Chem. Soc. 40, D. $25 ; 1918$.

- Bull. Assoc. Internationale du Froid, 6, No. 51; 2915.

6 Pogg. Ann. 46, p. 102; 1839 .

7 Phil. Trans. 135, D. 170; 1845 .
} 
terest than real importance. It is interesting to note, however, the remarkable agreement of Bunsen's figure near the normal boiling point with the later values.

Regnault ${ }^{2}$ published the results of three series of experiments by the static method. For each series a newly prepared sample was used. In the first series he states that a leak was discovered in his apparatus, which indicates very uncertain equilibrium conditions. In his remarks he states that in the experiments performed at constant temperature (the melting point of ice), after large variations in the space occupied by the vapor had been made, a long time was necessary for the liquid to come to temperature

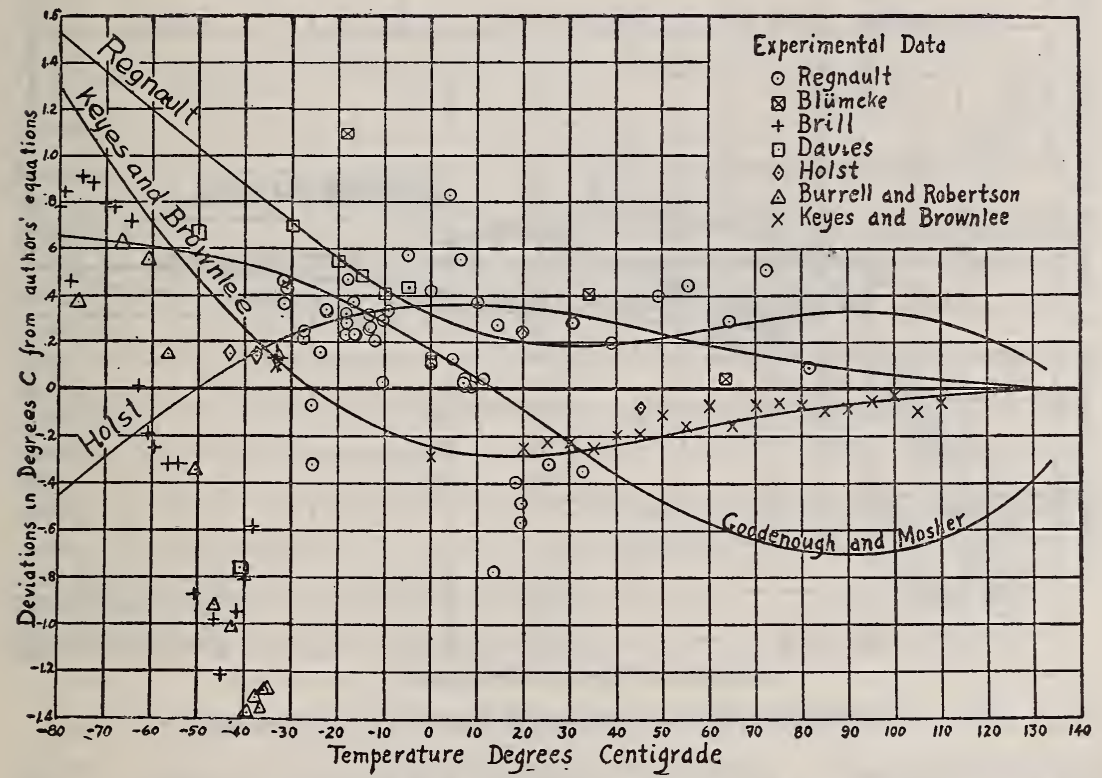

FIG. I.-Comparison of measurements of the vapor pressure of ammonia

equilibrium with the surrounding medium. This he attributed to the large heat capacity and large latent heat of vaporization of ammonia. A similar phenomenon, discussed in detail later, was experienced in the present work. The lag in coming to equilibrium at temperatures above $0^{\circ} \mathrm{C}$ was found by the authors to be large upon increase and relatively small upon decrease of vapor volume. Pressures measured soon after an increase of vapor volume gave various values much lower than those determined under equilibrium conditions, which may account for the rather large inconsistencies in Regnault's measurements and also for the fact that they are low. The curves marked "Regnault" in Figs. 
I and 2 are his own smoothed values represented by an empirical equation. The normal boiling point of ammonia calculated from this equation is $-32.6^{\circ} \mathrm{C}$. Regnault attempted to check this value by immersing a thermometer in.liquid ammonia exposed to the air in an open vessel and obtained the value $-38 . \mathrm{I}^{\circ} \mathrm{C}$ at $75^{2} \mathrm{~mm}$ pressure. It is now well known that liquid ammonia under these conditions will cool readily to nearly $-40^{\circ} \mathrm{C}$.

Pictet ${ }^{8}$ reported that he had made a series of vapor-pressure measurements in the temperature interval from $-30^{\circ}$ to $+50^{\circ} \mathrm{C}$

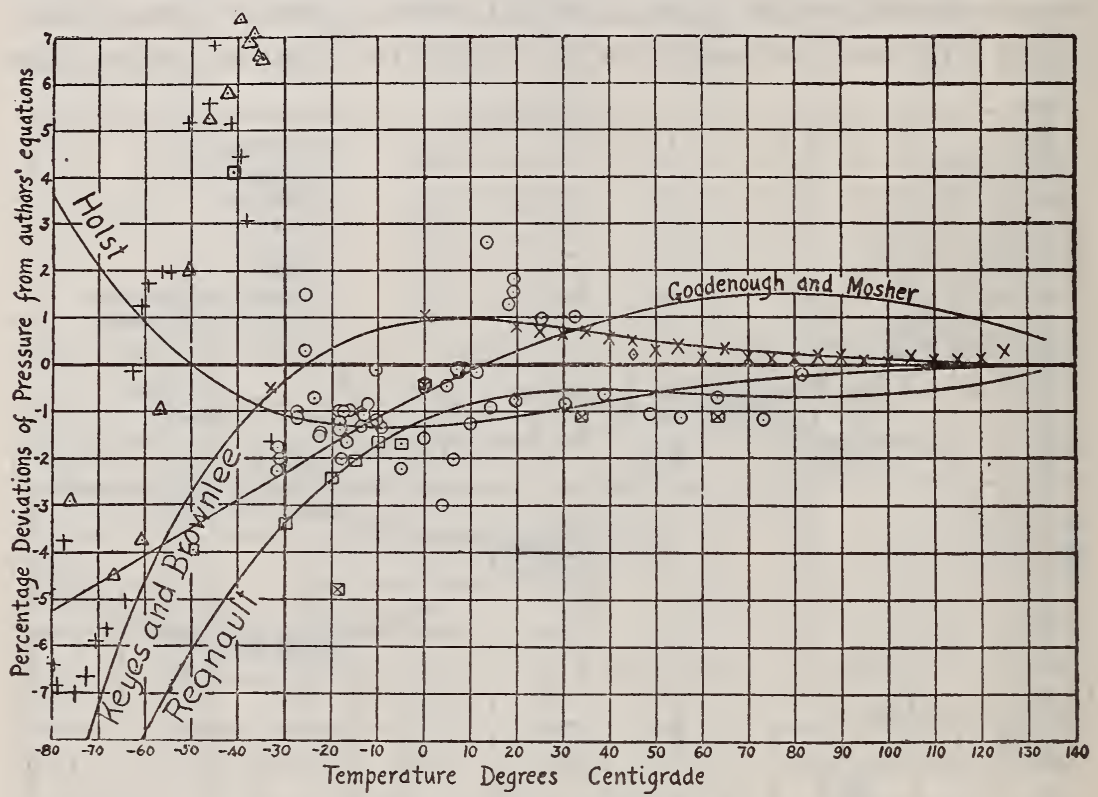

FIG. 2.-Comparison of measurements of the vapor pressure of ammonia

and gave merely a table of pressures for every 5 degrees. His values agree almost exactly with those computed by Regnault, and, therefore, are not included in Table $\mathrm{I}$.

Blümcke ${ }^{9}$ made four measurements within about the same temperature range. He remarks that no very large errors in the calibration of his closed-end air manometer and thermometers were present because of the good agreement between his results and those of Regnault.

Joannis, ${ }^{10}$ in his work with solutions of liquid ammonia, determined dynamically the boiling point of "pure" liquid ammonia as $-38.2^{\circ} \mathrm{C}$ at $764 \mathrm{~mm}$ pressure. No details of the determination

${ }^{8}$ Arch. sci. phys. nat. Genève (3), 13, p. 223; 1885.

2 Wied. Ann., 34, p. 18; 1888. 
are given, but the comparison with Regnault's result suggests that an open vessel was probably employed. He also found the vapor pressure of "pure" ammonia to be $845 \mathrm{~mm}$ at $-30.6^{\circ} \mathrm{C}$ and 779.3 $\mathrm{mm}$ at $-36 . \mathrm{I}^{\circ} \mathrm{C}$.

Gibbs ${ }^{11}$ made, perhaps, the first accurate measurement of the temperature of the normal boiling point. He obtained as a mean of six determinations $-33.46^{\circ} \mathrm{C}$. The dynamic method was employed and the thermometers, immersed in the boiling liquid, were observed to vary several hundredths of a degree during rather short intervals of time. Toluene thermometers were used which had been calibrated to within $0 . \mathrm{I}^{\circ} \mathrm{C}$ at the Reichsanstalt.

TABLE 2.-Determinations of the Normal Boiling Point of Ammonia

\begin{tabular}{|c|c|c|c|}
\hline Observer & Date & ${ }^{\circ} \mathrm{C}$ & Remarks \\
\hline Bunsen............ & 1839 & -33.4 & Observed $-33.7^{\circ} \mathrm{C}$ at $749.3 \mathrm{~mm}$. \\
\hline Loir and Drion.................... & 1860 & -35.7 & In an open vessel. \\
\hline Regnault............................. & 1862 & -37.9 & Observed $-38.1^{\circ} \mathrm{C}$ at $752 \mathrm{~mm}$ in an open vessel. \\
\hline Do.......................... & 1862 & -32.6 & Calculated from equation. \\
\hline Joannis......................... & 1893 & -38.3 & Probably in an open vessel. \\
\hline Ladenburg...................... & ....... & -35.0 & \\
\hline Lange............................ & …... & -33.7 & 1 \\
\hline Dickerson......................... & …... & -33.0 & \\
\hline De Forcrand...................... & 1903 & -32.5 & Vigorous boiling in an open vessel. \\
\hline Gibbs........................... & 1905 & -33.46 & \\
\hline Brill............................. & 1906 & -33.0 & \\
\hline Davies............................ & 1906 & -33.5 & $\begin{array}{l}\text { Interpolated graphically from measurements by } \\
\text { static method. }\end{array}$ \\
\hline Burrell and Robertson.............. & 1915 & -34.6 & \\
\hline Keyes and Brownlee............... & 1916 & -33.22 & \\
\hline Bureau of Standards................ & 1919 & -33.35 & \\
\hline
\end{tabular}

Several other normal boiling-point determinations have been made under various experimental conditions. Loir and Drion ${ }^{12}$ obtained the value $-35.7^{\circ} \mathrm{C}$, the ammonia being contained in an open vessel. De Forcrand ${ }^{13}$ measured the normal poiling point as $-32.5^{\circ} \mathrm{C}$ with a Baudin toluene thermometer immersed in liquid ammonia. Vigorous ebullition was produced by warming with the hand the large test tube containing the ammonia. Franklin ${ }^{14}$ states that observations taken in this manner yield values too high, due to the superheating of the liquid, and remarks also, that he has observed the low temperatures produced by liquid ammonia in an open vessel. Heconcludes, after careful consideration of the possible errors in Gibbs's work, that the value

11 J. Am. Chem. Soc., 27, p. 858; 1905 .

12 Bull. soc. chem , 2, p. 185; 1860. $152330^{\circ}-20-2$
${ }^{13}$ Ann. chem. phys. (7), 28, p. 537; 1903.

14 Ann. d. Physik (4), 24, p. $367 ;$;907. 
$-33.46^{\circ} \mathrm{C}$ is correct within $0.1^{\circ} \mathrm{C}$. Other determinations of the normal boiling point (original sources unobtainable) were made by Lange, ${ }^{15}$ Ladenburg, ${ }^{15}$ and Dickerson..$^{16}$

Brill ${ }^{17}$ has published his results on vapor-pressure measurements between the boiling and freezing points of ammonia. At the temperature $-79.2^{\circ} \mathrm{C}$, maintained constant by a bath of solid carbon dioxide and ether, he allowed hydrogen to pass over solid ammonia. The weight of ammonia in a known volume of hydrogen was determined by passing the gas mixture into dilute sulphuric acid and titrating. He then calculated the partial pressure of the ammonia by means of the ideal gas law and Dalton's law and obtained the value $36.5 \mathrm{~mm}$. At the higher temperatures he was unable to maintain the temperature constant long enough to permit determinations by this method. Consequently the static method was employed in the measurements recorded in Table $\mathrm{I}$. He admits great difficulty in keeping the temperatures constant, which suggests large errors due to the uncertainty of equilibrium. Temperatures were measured with an iron-constantan thermocouple checked against a pentane thermometer calibrated at the Reichsanstalt. The freezing point of pure chloroform was determined as a check and found to be $-63 \cdot \mathrm{I}^{\circ} \mathrm{C}$. Henning. ${ }^{18}$ found $-63.7^{\circ} \mathrm{C}$ as the temperature of this freezing point.

Davies ${ }^{19}$ made a series of vapor-pressure measurements by the static method at low temperatures in order to obtain an accurate value of the normal boiling point. Temperatures were measured with a pentane thermometer calibrated by comparison with an air thermometer. No provision was made for very precise temperature regulation of the alcohol and solid carbon-dioxide bath employed, which suggests the uncertainty of equilibrium.

Scheffer ${ }^{20}$ states that he made some measurements of the vapor pressure of ammonia which agreed with Regnault's results within the limits of his experimental error. No details or figures are recorded.

Burrell and Robertson ${ }^{21}$ made a series of measurements the results of which paralleled those made by Brill. The pentane thermometers used were calibrated at two fixed points as estab-

\footnotetext{
${ }^{15}$ Quoted in "Verflüssigtes Ammoniak als Lösungsmittel," by J. Bronn, Berlin; 1905.

${ }^{16}$ Quoted in "Liquid Air and Liquefaction of Gases," by T. O'Connor Sloane, London; 1900.

17 Ann. d. Physik (4), 21, p. 170; 1906.

${ }^{18}$ Ann. d. Physik (4), 43, p. 294; 1914

19 Proc. Roy. Soc., London (A), 78, p. 4r; 1906-7.

${ }^{20}$ Zeit. phys. chem., 71, p. 694; r9ro.

${ }^{21}$ J. Am. Chem. Soc., 37, p. 2482; I915.
} 
lished by Henning ${ }^{18}$ namely, the freezing point of mercury and the sublimation point of carbon dioxide at standard atmospheric pressure.

Holst ${ }^{22}$ made two measurements at about $+20^{\circ} \mathrm{C}$ and $+45^{\circ} \mathrm{C}$ in order to determine the proper weighting of Regnault's second and third series. Three measurements were also made near the normal boiling point to establish the slope of the vapor-pressure curve below this point. He remarks that many unforeseen difficulties were encountered in the latter measurements. Repeated attempts were made to use an apparatus analogous to that used by Kamerlingh Onnes and Braak ${ }^{23}$ in their determinations of the vapor pressures of oxygen, and pressures about ro per cent higher than Regnault's were consistently obtained. Holst finally employed a very wide tube provided with a stirrer and connected with a manometer of small volume. Pressures were then obtained which agreed well with Regnault's measurements. The curves marked "Holst" in Figs. I and 2 represent values computed from his empirical equation, which is based upon his own measurements and those of Regnault.

Keyes and Brownlee ${ }^{24}$ have published the results of their measurements with an absolute piston gage between $0^{\circ} \mathrm{C}$ and the critical temperature of ammonia. A special electrical contact method was employed to increase the sensitivity of the piston gage and to decrease the time necessary in making observations. The constant of the piston gage was determined by direct comparison with a mercury column. A 25 -ohm platinum resistance thermometer was used in the temperature measurements. Considerable care was taken in the purification of the ammonia used and the difficulty of removing dissolved gases was particularly emphasized. The ammonia vapor was absorbed in dry ammonium nitrate, making it possible to keep the ammonia at ordinary temperatures at a moderate pressure. It is stated that dissolved gases could be very completely removed from this ammonium nitrate-ammonia solution. Rather sensitive preliminary tests made at this Bureau indicate that the dissolved gases can not be removed with sufficient completeness by this method alone. The test used by Keyes and Brownlee for the absence of permanent gases was the complete collapsing of the vapor phase without rise in pressure. This may not be a very sensitive test due to the comparatively large solubility of gases in liquid ammonia. The attainment of

22 Bull. Assoc. Internationale du Froid, 6, p. 57; 1915.

${ }^{23}$ Comm. phys. lab., Leiden, No. 107 (a); 1908.

${ }^{24} \mathrm{~J}$. Am. Chem. Soc., 14, p. 25; 1918. 
equilibrium between the liquid and vapor required considerable time according to their experience. The lag appeared to be increased, it is stated, as the liquid was freed more perfectly from dissolved gases and was more pronounced at low temperatures. In our experience dissolved gases were found to increase greatly the lag in coming to equilibrium, as illustrated later in the measurements near the normal boiling point of a commercial sample which was known to contain air. In the absence of dissolved gases the lags were not excessive in our experiments, except in the measurements at temperatures above about $+25^{\circ} \mathrm{C}$, which was due to a thermal lag in the glass apparatus used.

The normal boiling point of ammonia was measured by Keyes and Brownlee by the static and also the dynamic method. The measurements by the static method were very discordant, due to the admitted difficulty in maintaining a constant bath temperature. The results obtained are given in a table in which all the measurements are corrected to the temperature $-33^{\circ} \mathrm{C}$ and show variations over a range of $40 \mathrm{~mm}$. A direct determination was then made by the dynamic method using a Beckman thermometer immersed in the liquid and a small heating coil to produce ebullition. The normal boiling point was observed to be a function of the heating current, varying from $-33.13^{\circ} \mathrm{C}$ with no current to $-33.70^{\circ} \mathrm{C}$ with four amperes. The most probable value of the normal boiling point by this method was chosen as $-33.2 \mathrm{I}^{\circ} \mathrm{C}$.

The table containing all their experimental data corrected to integral degrees of temperature shows variations of about 0.5 per cent in the individual measurements, made at a given temperature. The deviations of the mean of the observations corrected to integral degrees of temperature are shown in Figs. I and 2. The curves marked "Keyes and Brownlee" represent the deviations of values computed by their empirical equation from the present auchors' equations.

\section{GENERAL DESCRIPTION OF APPARATUS AND METHOD}

MANOMETERS.-The manometers used in making the present measurements were of three types, as shown in Fig. 3. The glass tubes used in each type were of $7 \mathrm{~mm}$ internal diameter and $\mathrm{I} .5$ mm wall thickness. A calibrated metric scale etched on a strip of silvered plate glass was attached directly behind each manometer.

Type $A$ consists of a glass $U$ tube containing mercury, with one arm evacuated and sealed and the other arm connected to a 
Scientific Papers of the Bureau of Standards, Vol. 16

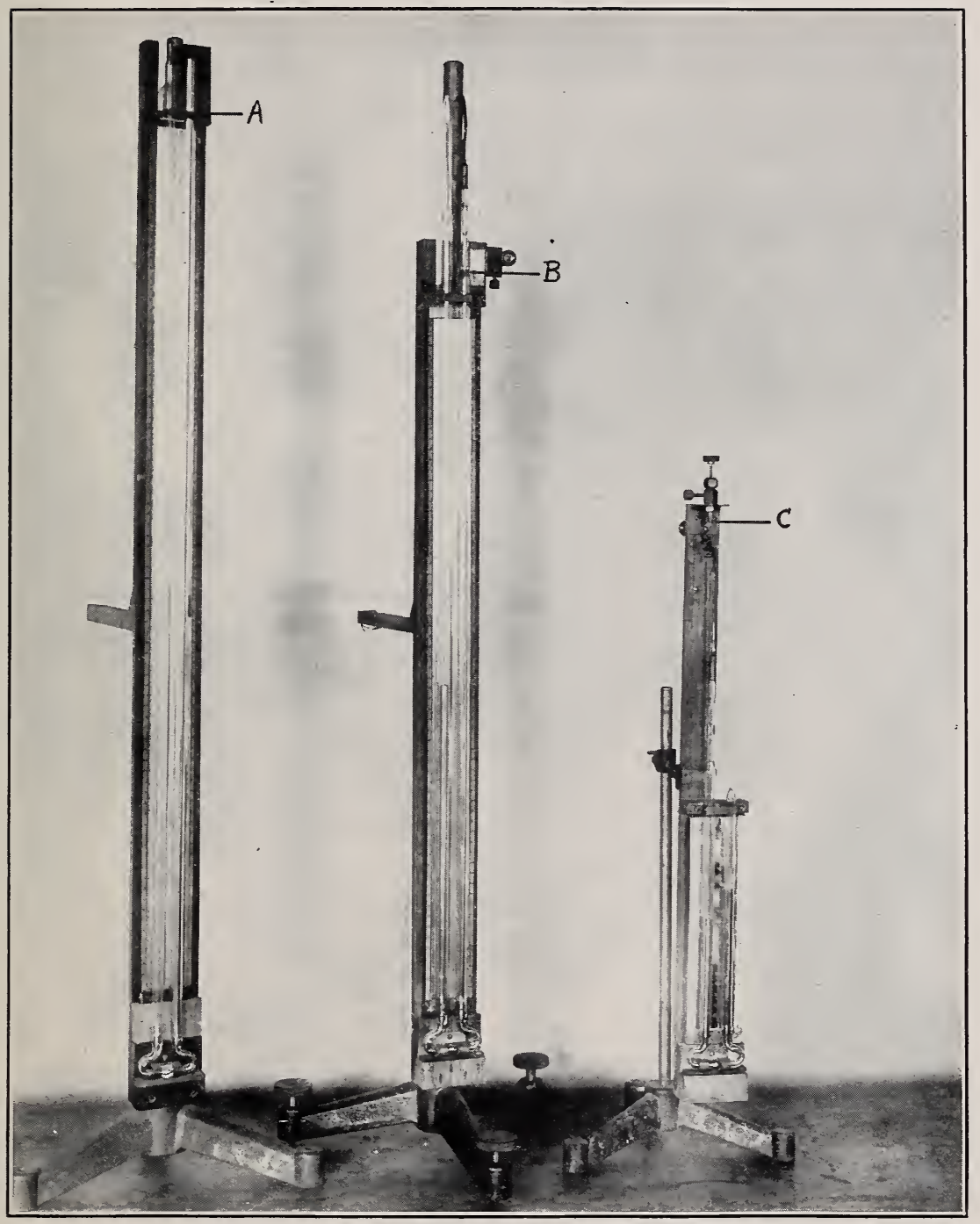

FIG. 3.-Hermetically sealed ammonia containers 
bulb containing the liquid ammonia. The pressure in this type and also in type $B$ is transmitted from the liquid ammonia contained in the small bulb and maintained at constant temperature to the mercury manometer by means of superheated ammonia vapor. Type $A$ was used in the measurements from $-78^{\circ} \mathrm{C}$ to the normal boiling point.

Two manometers of the type $B$ were used in measuring pressures from slightly below the normal boiling point to that corresponding to $+25^{\circ} \mathrm{C}$. This type is similar to the former except that one arm is here attached, through a glass-steel joint and a short spiral coil of flexible copper tubing to a brass needle valve. A small glass float fitting loosely at the bottom and ground at the top is also contained in this arm to act as a check valve to preserve the ammonia in case of a sudden release of the balancing pressure. Measurements near the normal boiling point were made by opening the brass valve to atmospheric pressure. Manometer and barometer readings were then taken simultaneously. At the higher pressures a balance was obtained by admitting pressure from a cylinder of compressed air, connected by copper tubing to the brass valve. A steel bomb of about 3 liters capacity was inserted in the connecting line and immersed in a large insulated bath of liquid at room temperature to damp out, during any series of measurements, the effect of small changes in room temperature on the pressure of this constant volume of air.

Two manometers of the type $C$ were used to measure the higher pressures corresponding to temperatures above room temperature. In this case the liquid ammonia was inclosed in one arm of the manometer and the whole manometer immersed in a thermoregulated bath. Air pressure was used here, as before, to obtain a balance in pressure within a few centimeters, and manometer readings were taken through a window in the bath.

PRESSURE GAGES.-An open mercury manometer was used to measure balancing pressures from I to $\mathrm{I}_{5}$ atmospheres. This manometer will be described in detail elsewhere, ${ }^{25}$ and only a brief description will be given here. It consists of five glass $U$ tubes, each having a length equivalent to 3 atmospheres pressure. By a proper manipulation of valves the $U$ tubes may be connected in series or by-passed to measure any pressure from $I$ to $\mathrm{I} 6$ atmospheres. The pressure is transmitted between tubes by a liquid of known density, alcohol in the present case. Readings

25 Dickinson and Meyers (to be published shortly as a Bureau Scientific Paper). 
of the mercury levels in the various arms are made upon accurately calibrated metric scales of steel. A specially constructed and calibrated mercury thermometer with a bulb 2.4 meters in length is used to measure the average temperature of the mercury columns.

The piston gage used to measure the higher balancing pressures will be described in detail in a separate paper. ${ }^{25}$ It was designed and constructed to measure pressures up to roo atmospheres. The pressure measurements were made by weighing the force exerted against a rotating steel piston floating in oil. The piston has an area of about I square centimeter. A small mercury manometer, from which the pressure is transmitted to the piston by means of oil, serves to indicate when the piston is in equilibrium.

CONSTANT TEMPERATURE BATHS.-The thermoregulated bath used in the measurements below room temperature with manometers of types $A$ and $B$ has been previously employed in the determination of specific and latent heats of ammonia and described in detail elsewhere. ${ }^{26}$ It consists of a brass vessel, with two cylindrical vertical tubes connected at the bottom and near the top, filled with gasoline. The smaller tube contains a screw propeller, electric heating coil, carbon dioxide cooling coil, and a thermostat coil filled with toluene. An oscillating contact in the thermostat head, previously described ${ }^{27}$ served to maintain the temperature constant to about one-thousandth of a degree.

In the measurements above room temperature a large thermoregulated bath of about roo liters capacity was used. This bath consists of half of a wooden barrel filled with water and provided with a stirrer, heating coil, and thermostat. Evaporation to the room provided the necessary cooling, and by the use of the oscillating contact in the thermostat head the temperature of the bath could be maintained remarkably constant for long periods of time.

THERMOMETERS.-Platinum resistance thermometers of the four-lead potential-terminal type, with strain-free winding, previously described by Waidner and Burgess ${ }^{28}$ were used in all the temperature measurements. The Wheatstone bridge used in the observations of the platinum thermometer resistances has been previously described. ${ }^{29}$

26 Osborne, B.S. Bulletin, 14, p. 145; 1917 (Scientific Paper No. 30r).

${ }^{27}$ Sligh, J. Am. Chem. Soc. 42, p. 60: 1920.

28 B.S. Bulletin, 6, p. I54; rgro (Scientific Paper No. 124).

${ }^{29}$ Waidner, Dickinson, Mueller, and Harper, B.S. Bulletin, 11, p. 571; 1915 (Scientific Paper No. 24r). 


\section{PURIFICATION OF SAMPLES AND DESCRIPTION OF MANOMETER FILLINGS}

The ammonia used in these measurements was prepared by methods to be described in detail in an independent paper. Only a brief description of the process of purification will, therefore, be given here.

A sample of synthetic ammonia (designated sample $K$ in a previous analysis ${ }^{30}$ ), which proved to be extremely pure except for a small amount of water and noncondensing gases, was transferred by distillation into a special small steel container, which would hold about a kilogram. The first portion was distilled off and the middle portion distilled into a similar vessel containing metallic sodium, in the form of fine wire, to remove any remaining trace of water which was less than o.or per cent by weight. Following this preliminary dehydration and purification, the liquid was distilled into a high-pressure distillation apparatus, and fractionally distilled eight times, rejecting the first and last fractions (about one-tenth the total volume of liquid) in each distillation. The rejected first fractions were removed through a mercury seal in such a way as to discard the noncondensing gas present. After the above treatment, which was all of a preliminary nature, the final product was distilled into a vacuum fractional-distillation apparatus of glass and fractionally distilled at least ro times under widely different conditions of temperature and pressure, the first and last portions being rejected in each case.

Since the accuracy of the physical measurements depends largely upon the purity of the ammonia used, and especially upon having the amount of noncondensing gases reduced to a minimum, particular care was taken in the removal of these gases. The ammonia was, therefore, frozen with liquid air and the vapor then pumped off by means of a high-vacuum pump. The ammonia was then allowed to warm up until it was entirely liquid and some of the vapor allowed to escape through the mercury seal. It was again frozen with liquid air and the vapor pumped off, as before. This process was repeated several times. Finally the ammonia was frozen into small, flocculent crystals by its own evaporation, the resulting vapor being pumped off and discarded. During this series of operations samples were taken continually and the 
amount of noncondensing gas determined by a method previously outlined, ${ }^{31}$ to be described more in detail in a later paper.

The tests on the final samples of ammonia used in filling the vapor-pressure manometers gave the following results: Noncondensing gases in the vapor at $+25^{\circ} \mathrm{C}$ and $760 \mathrm{~mm}$ pressure, less than I part in 100000 , by volume; water, less than 0.003 per cent, by weight, which was practically the limit of sensitivity of the chemical test applied.

The vapor-pressure manometers were thoroughly cleaned with concentrated nitric and sulphuric acids, aqueous potassium hydroxide solution, and washed with distilled water. They were then sealed, one at a time, into the glass line of the vacuum-distillation apparatus. A flask containing about $50 \mathrm{~cm}^{3}$ of mercury, purified by the anode process and by distillation, was sealed into the connecting line in such a manner as to permit the mercury to be distilled into the manometers under a high vacuum. In one case a manometer of type $B$ was heated to $300^{\circ} \mathrm{C}$ in a specially constructed electric furnace, before filling with mercury, to drive off more completely any occluded gases. (The vapor-pressure measurements made with this manometer, designated $B_{1}$ in Table 5, show no systematic difference, however, from those made with other manometers, which were not given this treatment.) A portion of the purified ammonia was then distilled into each manometer, being frozen in finely divided crystals by means of liquid air. After a sufficient quantity had been distilled into the apparatus, the supply reservoir was cut off by closing an intervening stopcock and the vapor phase pumped off with the aid of a highvacuum pump. The manometers were finally sealed, with the vacuum pump still in operation.

\section{DESCRIPTION OF PRELIMINARY EXPERIMENTS}

In the preliminary experiments two phenomena were observed, which determined to a large extent the procedure adopted in the final measurements. A brief discussion of thein is, therefore, given here.

\section{HYSTERESIS IN AN IMPURE SAMPLE}

In the early stages of this investigation an attempt was made to determine the boiling point of a commercial sample of ammonia by measurements of the vapor pressure near the normal boiling point, using the static method. The apparatus used in these 
measurements was similar to type $B$ (Fig. 3), except that the open end of the manometer tube was drawn down to a small capillary and sealed. When the liquid ammonia in the bulb had been cooled to within a few degrees of the normal boiling point, the glass tip of the capillary was broken off to admit atmospheric pressure. The pressure was then determined from readings of the manometer and the barometer.

Fig. 4 illustrates the results obtained with a commercial sample known to contain air as compared with those obtained with a thoroughly purified sample almost completely freed from dissolved

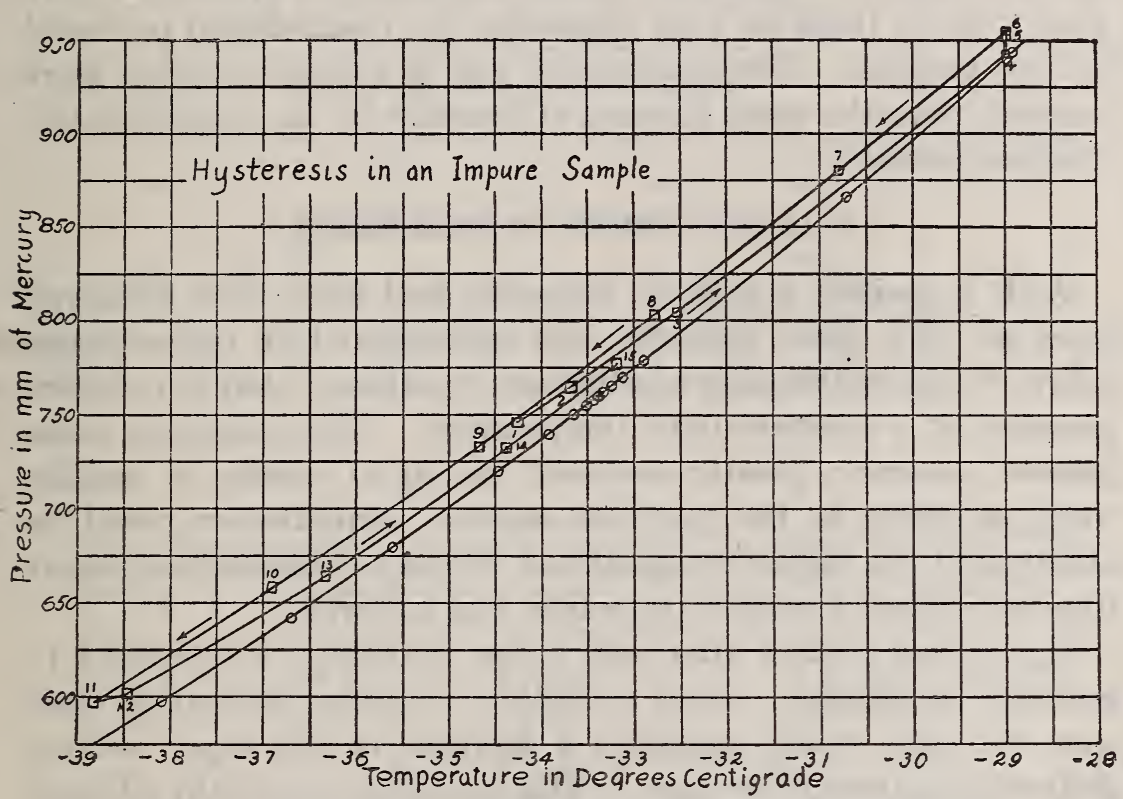

FIG. 4.-Comparison of measurements with a pure and impure sample

gases. The observations taken with the commercial sample are numbered in the order in which they were made. No definite procedure was followed in these measurements to insure equilibrium. Observations were made about five or ten minutes after the regulation of the bath at a constant temperature had been accomplished and consequently do not represent the system in equilibrium. The observations designated 4,5 , and 6 were made at a constant bath temperature; 4 soon after the bath tcmperature had been raised about $4^{\circ}, 5$ after an interval of one hour, and 6 fifteen minutes later. The lower curve represents the vapor-pressure measurements with a pure sample, taken with a similar apparatus and procedure, which show no evidence of hysteresis, but lie con$152330^{\circ}-20-3$ 
sistently on a smooth curve. The occurrence of hysteresis, at least with the type of apparatus here used, furnishes an excellent test of the presence of noncondensing gases, even in very small quantities.

The phenomenon of hysteresis is undoubtedly associated with the presence of noncondensing gases in the ammonia, but whether the phenomenon observed is due primarily to changes in the amount of gas in solution in the liquid or to changes in the distribution of the gas between the saturated and superheated vapor has not been determined. While the observed pressures were always above those for pure ammonia, the phenomenon produced by the presence of noncondensing gas is evidently much more complex than the mere increase of pressure by an approximately constant amount.

\section{LAG IN COMING TO EQUILIBRIUM}

With a purified sample of ammonia well freed from dissolved gases no very great difficulty was encountered at temperatures below $0^{\circ} \mathrm{C}$ in establishing equilibrium conditions; that is, constant pressure at a constant bath temperature. Noncondensing gases present, however, greatly increased the lag in coming to equilibrium, as shown in the previous section. Equilibrium could be obtained at the higher temperatures within a comparatively short time only when a certain procedure was followed.

Figs. 5 and 6 show that only a few minutes were required to establish equilibrium when a slightly excessive balancing pressure was used which produced a decrease in the vapor volume and condensation of the vapor. This procedure was finally adopted in all the vapor-pressure measurements. Much greater lags were observed when too small a balancing pressure was used, so that the vapor volume was increasing, which necessitated evaporation of the liquid. The lower curves shown in these figures were determined by first obtaining equilibrium conditions and then decreasing the balancing pressure a small amount, with the bath maintained at a constant temperature. The curve with increasing vapor volume at $+50^{\circ} \mathrm{C}$ indicates that equilibrium would have been reached only after some hours. A similar phenomenon was observed when the bath temperature was raised and the balancing pressure maintained constant.

Fig. 7 shows approximately the variation at different temperatures of the observed vapor pressure with the rate of change of vapor 

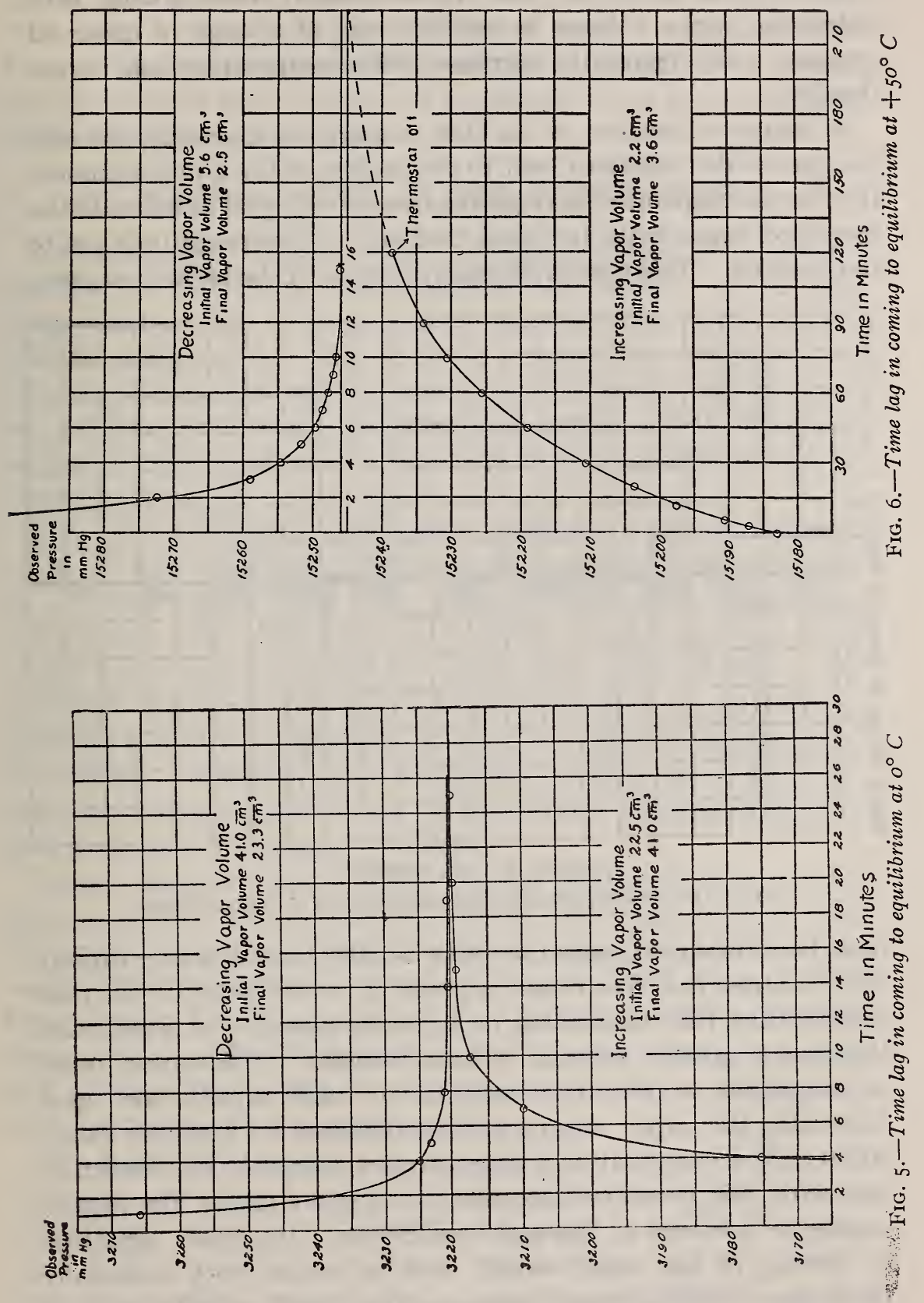
volume which corresponds in this case with the rate of change of observed total pressure. The lag is evidently much greater with increasing vapor volume or positive rate of change of observed pressure and apparently increases with temperature and vapor density.

A simple calculation of the time required to transmit, through the glass walls, sufficient heat to the surface of the liquid ammonia in order to evaporate the requisite amount of liquid to saturate the increased vapor space indicates that lags of this magnitude are to be expected. This time is obviously greater at the higher tempera-

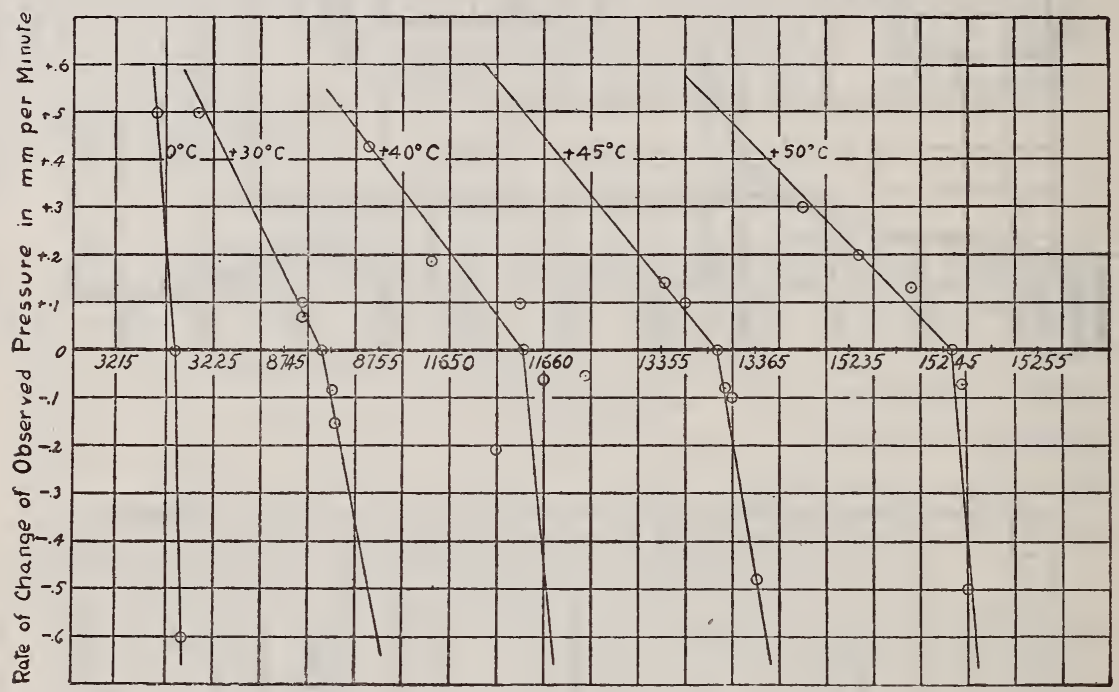

Pressure in $m m$ of Mercury

FIG. 7.-Preliminary measurements showing effect of nonequilibrium

tures here employed, since the vapor density increases very rapidly (for example, it is five times as great at $+50^{\circ}$ as at $0^{\circ} \mathrm{C}$ ), thus necessitating the evaporation of a greater quantity of liquid, and therefore a greater amount of heat transfer. The correct order of magnitude of the time required to reach equilibrium upon decreasing the vapor volume may be obtained by a similar calculation. The comparatively large surface available for condensation with this procedure decreases to a great extent the lags in coming to pressure or thermal equilibrium. Doubtless, agitation or stirring of the liquid would tend to reduce very materially these lags. With a metal container they would also be reduced due to the larger thermal conductivity of metal as compared with glass. 
All of the preliminary measurements, most of which are shown in Fig. 7 , have been discarded and no weight given to them in the final result. They were purposely made under very poor conditions to determine the most advantageous procedure to secure equilibrium and also to study the magnitude of the error produced in the pressure measurement.

\section{MEASUREMENTS BY THE STATIC METHOD}

MEASUREMENTS BELOW $-55^{\circ} \mathrm{C}$.-Measurements of the vapor pressure were made at three temperatures below $-55^{\circ} \mathrm{C}$, the lower limit of the thermoregulated gasoline bath with carbon dioxide refrigeration. The constant temperatures employed in these measurements were obtained at the freezing point of commercial chloroform, the triple point of ammonia and the temperature of a mixture of solid carbon dioxide and gasoline at atmospheric pressure.

The bulb containing the liquid ammonia of the manometer (type $A$ ) and a platinum resistance thermometer were immersed in a double-walled glass tube, partially filled with commercial chloroform. The glass tube and contents were placed in a bath of gasoline, which was cooled by adding solid carbon dioxide. No provision was made to prevent the condensation in the tube of moisture from the atmosphere, since only a constant temperature was desired. Stirring of the chloroform was produced mechanically and readings taken when the temperature became constant; that is, during the process of freezing.

Several determinations, which will be published later, of the freezing point of pure ammonia under its own vapor pressure (the triple point) have been made in a special apparatus provided with a resistance thermometer and a stirrer operated from the outside by a magnet. Measurements of vapor pressure at this point were made with a small mercury manometer attached to this apparatus and readings taken with a cathetometer. Meniscus corrections were applied to the manometer readings.

The manometer of type $A$ was used in the vapor-pressure measurements with a carbon dioxide-gasoline slush bath. The temperature of the slush bath was measured in the first experiment with a platinum resistance thermometer and in another experiment with a carbon dioxide vapor-pressure thermometer. 
TABLE 3.--Sample Record Sheet: Pressures by Mercury Manometer

Observers: R. S. J., C. S. C., and C. H. M.

Date: - May 15, 1919

AMMONIA SAMPLE $B_{4}$

\begin{tabular}{|c|c|c|c|c|c|c|c|c|c|c|}
\hline Time.. & $3: 18$ & $3: 23$ & $3: 28$ & $3: 33$ & ... & $4: 12$ & $4: 17$ & $4: 23$ & $4: 28$ & \\
\hline Manometer temp. & $24.6^{\circ}$ & $24.6^{\circ}$ & $24.6^{\circ}$ & $24.6^{\circ}$ & & $27.1^{\circ}$ & $27.1^{\circ}$ & $27.2^{\circ}$ & $27.3^{\circ}$ & \\
\hline Temp. corrected. . & $24.5^{\circ}$ & $24.5^{\circ}$ & $24.5^{\circ}$ & $24.5^{\circ}$ & & $26.9^{\circ}$ & 26.9 ? & $27.0^{\circ}$ & $27.1^{\circ}$ & \\
\hline Factor: $\mathrm{C}_{2} \mathrm{H}_{5} \mathrm{OH}$ to $\mathrm{mm} \mathrm{Hg}=$ & 0.05781 & 0.05781 & 0.05781 & 0.05781 & & 0.05766 & 0.05766 & 60.05765 & 50.5765 & \\
\hline $\mathbf{F}_{1}$ & & & & $=$ & & & & & & \\
\hline Factor: $\left(\mathrm{Hg}-\mathrm{C}_{2} \mathrm{H}_{5} \mathrm{OH}\right)=\mathrm{F}_{2}$. & 0.93718 & 0.93718 & 0.93718 & 0.97318 & & 0.93689 & 90.93689 & 90.93687 & 70.93686 & $5 . \ldots$. \\
\hline $\mathrm{Mm} \mathrm{C}_{2} \mathrm{H}_{5} \mathrm{OH} \ldots \ldots \ldots \ldots$ & -550 & -550 & -549 & -549 & ... & -153 & -152 & -146 & -145 & $5 \ldots$. \\
\hline $\int \mathrm{C}_{2} \mathrm{H}_{5} \mathrm{OH} \ldots \ldots \ldots$ & 112.85 & 114.05 & 115.20 & 116.80 & & 132.30 & 133.80 & \begin{tabular}{l|l}
0 & 138.30
\end{tabular} & 139.70 & \\
\hline Aux. H.P. gas........... & 118.30 & 119.75 & 121.05 & 122.10 & & 136. 90 & 138.20 & $0 \quad 142.20$ & 143.90 & $\ldots \ldots$ \\
\hline Aux. L. P. $\left\{\mathrm{C}_{2} \mathrm{H}_{5} \mathrm{OH} \ldots\right.$ & $\ldots$ & $\ldots \ldots \ldots$ & $\cdots$ & $\ldots \ldots \ldots$ & & ......... & $\ldots \ldots$ & $-\ldots \ldots$ & $\ldots \ldots$ & 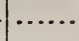 \\
\hline frdg. upper scale $\ldots \ldots$ & r...... & r...... & ( 33.30 & 32.75 & & 41.90 & 41.10 & 0.31 .10 & 30.10 & \\
\hline $\mathrm{U}_{1}\left\{\begin{array}{l}\text { rdg. lower scale ......... }\end{array}\right.$ & 76.80 & 77.65 & 78.30 & 79.00 & & 98.80 & 100.00 & 90.90 & 91.80 & $\cdots \cdots$ \\
\hline rdg. upper scale ..... & 34.30 & 33.80 & 32.95 & 32.20 & & 41.90 & 41.10 & 42.90 & 42.00 & $\ldots \ldots$ \\
\hline $\begin{array}{l}{ }_{2}\{\text { rdg. lower scale ..... } \\
\text { rdg. upper scale ..... }\end{array}$ & 36.30 & 35.75 & $\begin{array}{r}35.10 \\
\ldots\end{array}$ & 34.30 & . & 44.00 & 43.20 & 45.00 & 44.20 & $\ldots$ \\
\hline$\left\{\begin{array}{l}\text { rdg. lower scale .... } \\
\text { rdg. upper scale.... }\end{array}\right.$ & & & & & & & & & & an. \\
\hline $\mathrm{U}_{4}\{$ rdg. lower scale. & & & & & & & & ... & $\ldots \ldots$ & ... \\
\hline Us rdg. upper scale.... & 2163.70 & 2162.80 & 2161.70 & 2161.00 & & 2542.10 & 2541.40 & 02543.70 & 2542.80 & .. \\
\hline & 2577.00 & 2577.85 & 2577.60 & 2578.15 & & 3037.90 & 3038.80 & 03034.10 & 03034.50 & \\
\hline Distance betweenscale zeros. & 4487.56 & 4487.56 & 4487.56 & 4487.56 & & 4487.66 & 54487.66 & 64487.66 & 54487.66 & 5. \\
\hline & 7064.56 & 7065.41 & 7065.16 & 5065.71 & & 7525.56 & 57526.46 & 67521.76 & 67522.16 & \\
\hline - $\mathrm{U}_{5} \mathrm{rdg}$. upper scale... & 920.00 & 921.00 & 921.80 & 923.00 & & 545.10 & 0546.00 & \begin{tabular}{l|l}
0 & 543.80
\end{tabular} & 0) 544.50 & .... \\
\hline $\mathrm{Mm}\left(\mathrm{Ig}-\mathrm{C}_{2} \mathrm{H}_{5} \mathrm{OH}\right) \ldots \ldots$ & 6144.56 & 6144.41 & 6143.36 & 66142.71 & & 6980.46 & 6980.46 & 66977.96 & 56977.66 & \\
\hline $\mathrm{F}_{1} \times \mathrm{mm}=\mathrm{mmHg} \ldots$ & -31.8 & -31.8 & -31.8 & 3) -31.8 & & -8.8 & -8.8 & -8.4 & -8.4 & \\
\hline $\mathrm{F}_{2} \times \mathrm{mm}=\mathrm{mmHg} \ldots$ & 5758.5 & 5758.4 & 4) 5757.4 & 7) 5756.8 & & 6540.0 & 0) 6540.0 & 0 0) 6537.6 & 5) 6537.2 & $\ldots$ \\
\hline Pressure diff. & 5726.7 & 5726.6 & 5725.6 & 5725.0 & & 6531.2 & 2) 6531.2 & 2) 6529.2 & 2) 6528.8 & \\
\hline Barom. temp. corrected. . & $22.8^{\circ}$ & $22.8^{\circ}$ & $22.9^{\circ}$ & $23.0^{\circ}$ & 0. & $23.0^{\circ}$ & $22.8^{\circ}$ & $23.0^{\circ}$ & $23.1^{\circ}$ & \\
\hline $1+$ & 792.00 & 791.92 & 791.83 & 792.00 & 0. & 791.86 & 791.82 & \begin{tabular}{l|l}
2 & 791.82
\end{tabular} & 2) 791.92 & \\
\hline Barom. $\{-\ldots \ldots \ldots \ldots \ldots . .6$ & 42.04 & 42.14 & 42.14 & 42.12 & 2. & 42.24 & 42.13 & 42.14 & 42.18 & $8 .$. \\
\hline Lat.,alt., and temp.corrections & -3.22 & -3.22 & -3.23 & -3.24 & $4 .$. & -3.24 & -3.22 & $2-3.24$ & 4) -3.26 & $5 \ldots \ldots$ \\
\hline Corrected barom. & 746. 74 & 746.56 & 5746.46 & 5) 746.64 & & 746.38 & 746.47 & 746.44 & 4) 746.49 & \\
\hline Jright arm........ & 351.4 & 351.75 & 351.9 & 352.1 & & 492.3 & 492.8 & 493.3 & 493.4 & \\
\hline left arm . . . . . . & 393.25 & 393.0 & 392.8 & 392.6 & 5. & 244.6 & 244.1 & 243.7 & 243.6 & 5 \\
\hline Lat.,alt., and temp.corrections & -0.21 & -0.21 & -0.21 & -0.21 & $1 \ldots$ & -1.34 & $4-1.34$ & $4-1.35$ & -1.35 & $\ldots \ldots$ \\
\hline $\mathrm{NH}_{3}$ mano. press. corrected. & -41.6 & -41.0 & -40.7 & -40.3 & & 246.4 & 247.4 & 248.3 & 248.5 & \\
\hline Total obs. press...... & 6431.8 & 6432.2 & 6431.4 & 6431.3 & & 7524.0 & 7525.1 & 7523.9 & 7523.8 & \\
\hline Gas column correction .. & +1.1 & 1.1 & 1.1 & 1.1 & 1 Mean. & +1.2 & 1.2 & 1.2 & 1.2 & Mean. \\
\hline Vapor & 6432.9 & 6433.3 & 6432.5 & 6432.4 & 7) 6432.8 & 7525.2 & 7526.3 & 37525.1 & 7525.0 & 7525.4 \\
\hline Temp. $\mathrm{NH}_{3}$. & $+20.019^{\circ}$ & $20.019^{\circ}$ & $20.019^{\circ}$ & $20.017^{\circ}$ & $20.018^{\circ}$ & $+25.014^{\circ}$ & $25.016^{\circ}$ & - $25.016^{\circ}$ & $25.017^{\circ}$ & $25.016^{\circ}$ \\
\hline
\end{tabular}




\section{TABLE 4.-Sample Record Sheet: Pressures by Piston Gage}

Observers: C. S. C. and C. H. M.

Date: May 23, 1919

AMMONIA SAMPLE $\mathrm{C}_{1}$

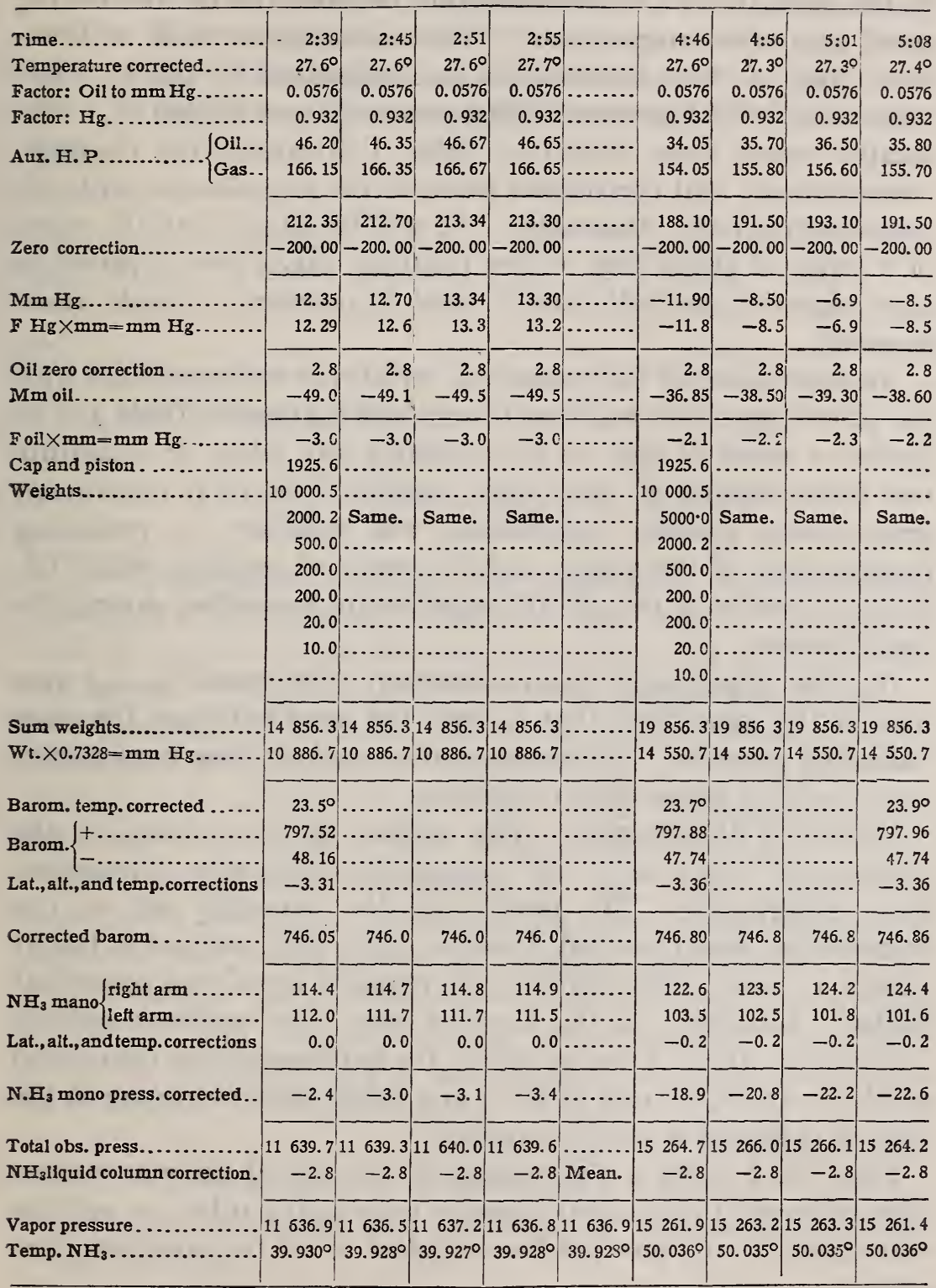


MEASUREMENTS ABove $-55^{\circ} \mathrm{C}$ - - Manometers of types $A$ and $B$ were used in the measurements from $-55^{\circ} \mathrm{C}$ to the normal boiling point of ammonia. Two manometers of type $B$ were used in the majority of the measurements between the normal boiling point and room temperature. The measurements made with the first filling of these manometers are designated $B_{1}$ and $B_{3}$ while those made with the second filling are designated $B_{2}$ and $B_{4}$. The sample record sheet shown in Table 3 illustrates the readings, computations, and corrections made in the experiments with the open-end mercury manometer. It will be noted that the mean of a series of about four or five readings, taken over a period of approximately one-half hour, is used to represent a single measurement.

An illustration of the manner in which the measurements with the piston gage were made and computed is given in Table 4. As before, a series of four or five readings was taken to constitute one measurement of the vapor pressure. In each experiment approximate pressure equilibrium was obtained by producing condensation of the vapor, and the series of readings which followed served as a test of the equilibrium prevailing during the measurement.

In a few experiments two manometers (designated $B_{4} B_{2}$ ) were used at the same time; that is, with the same bath and the same balancing pressure. The pressures measured on these manometers were identical under these conditions.

MENISCUS DEPRESSION. - The heights of the menisci in the manometer tubes were not measured consistently throughout these experiments. The menisci on the ammonia side of the manometers were observed, however, to be very uniform in height (about $\mathrm{r} .5 \mathrm{~mm}$ ), while those in the opposite arms were somewhat flatter. Assuming, in the extreme case, one meniscus entirely flat and the other $1.5 \mathrm{~mm}$ in height, the maximum error introduced would be about $0.8 \mathrm{~mm}$ in the $7 \mathrm{~mm}$ tubes used, according to the data of Mendelejeff and Gutkowski. ${ }^{32}$

Since the heights of the menisci in one arm of the manometers were observed to be slightly greater than in the other, a uniform correction of $-0.3 \mathrm{~mm}$ has been applied to all the observed pressures.

UNIT OF PRESSURE.-All of the pressure measurements were reduced to mm of mercury at $0^{\circ} \mathrm{C}$ and to standard gravity 
$(g=980.665)^{33}$ the value of $g$ in this laboratory is $980.09 \mathrm{I}$, based on a direct determination made by the U. S. Coast and Geodetic Survey in $1910 .{ }^{34}$

TEMPERATURE SCALE.-The platinum resistance thermometers used in all the temperature measurements were calibrated in ice, steam, and sulphur vapor $\left(444.6^{\circ} \mathrm{C}\right.$ taken as the normal boiling point of sulphur). The constants determined by this calibration are:

\begin{tabular}{|c|c|c|c|c|}
\hline$=2$ & Thermometer & $R_{0}$ & $R_{100}-R_{0}$ & $\delta$ \\
\hline $\mathrm{C}_{21} \ldots \ldots \ldots \ldots$ & & 25.5440 & 9.9958 & 1.491 \\
\hline $\mathrm{C}_{22} \ldots \ldots \ldots$ & & 25.5484 & 9.9876 & 1.495 \\
\hline $\mathrm{C}_{23} \ldots \ldots \ldots \ldots$ & & 25.5345 & 9.9865 & 1.488 \\
\hline
\end{tabular}

Using the Callendar equation

$$
t=\frac{R_{t}-R_{0}}{R_{100}-R_{0}} \mathrm{IOO}+\delta\left(\frac{t}{\mathrm{IOO}}-\mathrm{I}\right) \frac{t}{\mathrm{IOO}}
$$

as an interpolation equation, the temperature scale so defined represents the centigrade thermodynamic scale in the interval $-40^{\circ}$ to $+450^{\circ} \mathrm{C}$ to the accuracy with which that scale is at present known. The scale defined by the resistance thermometer of pure platinum has been adopted as the standard working scale of the Bureau of Standards for use in the interval $-40^{\circ}$ to $+450^{\circ} \mathrm{C}$. Temperatures between $0^{\circ}$ and $+100^{\circ} \mathrm{C}$ may be measured on this scale with a precision of a few thousandths of a degree. Below $-40^{\circ} \mathrm{C}$ temperatures determined by the above equation are consistently lower than those determined with a gas thermometer. By direct comparison of several resistance thermometers of very pure platinum with a constant-volume hydrogen thermometer, Henning ${ }^{35}$ found that the following corrections were necessary to reduce to the gas scale the temperatures determined with these thermometers, by means of the Callendar equation; +o.or ${ }^{\circ}$, $+0.06^{\circ}$, and $+0.16^{\circ}$ at $220^{\circ}, 200^{\circ}$, and $180^{\circ}$ absolute, respectively. The temperature measurements below $-40^{\circ} \mathrm{C}$ in this work have accordingly been corrected by interpolation between these corrections.

\footnotetext{
${ }^{33}$ This value was adopted by the International Committee on. Weights and Measures in rgor. (Traveaux et Mémoires du Bur. Int., third general conference, p. 66; r902).

34 B. S. Bulletin, 8, p. 363 ; r9I2 (Scientific Paper No. r7x).

is Ann. d. Physik (4), 40, p. 653 ; г913.
} 
RESULTS. -The results of all the measurements by the static method, except the preliminary measurements previously referred to as having been rejected, are given in Table 5 , which gives the date of the experiment, the sample used, the observed temperatures and pressures, and the deviations in mm of mercury of the observed values from the empirical equations, given in Section IX.

TABLE 5.-Measurements of Vapor Pressure of Ammonia by the Static Method

\begin{tabular}{|c|c|c|c|c|c|c|c|c|c|}
\hline Date & Sample & $\begin{array}{l}\text { Obs. } \\
\text { temp., } \\
{ }^{\circ} \mathrm{C}\end{array}$ & $\begin{array}{c}\text { Press. } \\
\text { obs. by } \\
\text { manom- } \\
\text { eter, } \\
\text { mm Hg }\end{array}$ & $\begin{array}{c}\text { Devia- } \\
\text { tions } \\
\text { trom } \\
\text { equa- } \\
\text { tion, } \\
\text { mm Hg }\end{array}$ & Date & Sample & $\begin{array}{l}\text { Obs. } \\
\text { temp., } \\
{ }^{\circ} \mathbf{C}\end{array}$ & $\begin{array}{c}\text { Press. } \\
\text { obs. by } \\
\text { manom- } \\
\text { eter, } \\
\text { mm Hg }\end{array}$ & $\begin{array}{l}\text { Devia- } \\
\text { tions } \\
\text { from } \\
\text { equa- } \\
\text { tion, } \\
\text { mm Hg }\end{array}$ \\
\hline June 25, 1919 & $\mathbf{A}$ & -78.44 & 42.2 & -0.6 & Nov. 22, 1918 & $\mathbf{A}$ & -36.667 & 641.2 & -0.4 \\
\hline Do........ & A & -78.45 & 42.8 & +0.1 & Do...... & $\mathbf{A}$ & -36.645 & 642.5 & +0.2 \\
\hline July 26,1919 & Special & -77.70 & 44.9 & -0.4 & Mar. 28, 1919 & $\mathrm{C}_{2}$ & -36.616 & 643.6 & +0.3 \\
\hline June 26, 1919 & $\mathbf{A}$ & -64.50 & 121.2 & 0.0 & Dec. 2,1918 & $\mathbf{A}$ & -36.605 & 643.5 & -0.2 \\
\hline June 25, 1919 & $\mathbf{A}$ & -64.27 & 122.8 & -0.3 & Nov. 30,1918 & $\mathbf{A}$ & -35.476 & 682.5 & +0.2 \\
\hline Mar. 14, 1919 & $\mathbf{B}_{1}$ & -53.036 & 256.3 & +0.9 & Nov. 26,1918 & $\mathbf{A}$ & -34.907 & 702.8 & +0.4 \\
\hline Nov. 22,1918 & $\mathbf{A}$ & -51.760 & 276.6 & +0.7 & Do....... & $\mathbf{A}$ & -34.119 & 731.1 & +0.1 \\
\hline Nov. 30,1918 & $\mathbf{A}$ & -51.603 & 278.9 & +0.3 & Nov. 30,1918 & $\mathbf{A}$ & -33.746 & 745.1 & +0.2 \\
\hline Mar. 15, 1919 & $\mathbf{B}_{1}$ & -50.717 & 294.5 & +0.7 & Nov. 23, 1918 & $\mathbf{A}$ & -33.389 & 758.7 & +0.3 \\
\hline Mar.18, 1919 & $\mathbf{B}_{3}$ & -50.717 & 294.4 & +0.6 & May 2,1919 & $\mathbf{B}_{4}$ & -33.369 & 760.2 & +0.1 \\
\hline Mar.14, 1919 & $\mathbf{B}_{1}$ & -48.495 & 335.2 & +0.3 & Apr. 15,1919 & $\mathbf{B}_{2}$ & -33.368 & 759.3 & +0.1 \\
\hline Nov. 30,1918 & $\mathbf{A}$ & -48.172 & 341.9 & +0.6 & May 5,1919 & $\mathbf{B}_{4}$ & -33.363 & 760.1 & +0.7 \\
\hline Nov. 22, 1918 & $\mathbf{A}$ & -47.781 & 349.5 & +0.4 & Apr. 17,1919 & $\mathbf{B}_{2}$ & -33.362 & 760.0 & +0.5 \\
\hline Do.-..... & $\mathbf{A}$ & -47.620 & 352.3 & -0.1 & Mar. 28, 1919 & $\mathrm{C}_{2}$ & -33.361 & 760.1 & +0.6 \\
\hline Nov. 26, 1918 & $\mathbf{A}$ & -45.946 & 388.3 & +0.5 & Do....... & $\mathrm{C}_{2}$ & -33.354 & 760.1 & +0.4 \\
\hline Nov. 30,1918 & $\mathbf{A}$ & -44.597 & 419.0 & +0.5 & Mar. 18, 1919 & $\mathbf{B}_{3}$ & -33.314 & 761.6 & +0.3 \\
\hline Nov. 22,1918 & $\mathbf{A}$ & -44.270 & 426.2 & 0.0 & Nov. 22,1918 & $\mathbf{A}$ & -33.305 & 761.2 & -0.4 \\
\hline Do........ & A & -44.169 & 428.6 & 0.0 & Do....... & $\mathbf{A}$ & -33.297 & 761.3 & -0.6 \\
\hline Mar. 14, 1919 & $\mathbf{B}_{1}$ & -44.059 & 431.9 & +0.7 & Do....... & $\mathbf{A}$ & -33.283 & 762.2 & -0.3 \\
\hline Mar.15, 1919 & $\mathrm{~B}_{1}$ & -44.034 & 432.4 & +0.6 & Mar. 15, 1919 & $\mathbf{B}_{1}$ & -33.270 & 763.4 & +0.4 \\
\hline Mar. 18, 1919 & $\mathbf{B}_{3}$ & -43.937 & 434.3 & +0.1 & Nov. 30, 1918 & $\mathbf{A}$ & -33.257 & 763.4 & -0.1 \\
\hline Nov. 30,1918 & $\mathbf{A}$ & -43.423 & 446.9 & +0.1 & Do....... & $\mathbf{A}$ & -33.250 & 763.7 & 0.0 \\
\hline Nov. 26,1918 & $\mathbf{A}$ & -42.476 & 471.2 & +0.5 & Dec. 3,1918 & $\mathbf{A}$ & -33.244 & 763.6 & -0.4 \\
\hline Nov. 22,1918 & $\mathbf{A}$ & -40.274 & 530.6 & +0.2 & Mar.17, 1919 & $\mathbf{A}$ & -33.243 & 764.3 & +0.3 \\
\hline Do,$\ldots \ldots$... & $\mathbf{A}$ & -40.240 & 531.8 & +0.5 & Mar. 15, 1919 & $\mathbf{B}_{1}$ & -33.241 & 764.5 & +0.4 \\
\hline Mar. 14, 1919 & $\mathrm{~B}_{1}$ & -38.875 & 572.0 & +0.5 & Mar. 14, 1919 & $\mathbf{B}_{1}$ & -33.123 & 768.9 & +0.3 \\
\hline Nov. 30,1918 & $\mathbf{A}$ & -38.873 & 571.6 & 0.0 & Mar. 28, 1919 & $\mathrm{C}_{2}$ & -30.451 & 877.4 & -0.2 \\
\hline Dec. 3,1918 & $\mathbf{A}$ & -38.873 & 571.3 & -0.3 & Aps. 16,1919 & $\mathbf{B}_{2}$ & -30.081 & 893.3 & +0.1 \\
\hline Do......... & $\mathbf{A}$ & -38.873 & 571.9 & +0.3 & May 2,1919 & $\mathbf{B}_{4}$ & -30.038 & 895.8 & +0.8 \\
\hline Dec. 2,1918 & $\mathbf{A}$ & -38.872 & 571.7 & +0.1 & May 10,1919 & $\mathrm{B}_{4}$ & -30.011 & 897.1 & +0.9 \\
\hline Nov. 30, 1918 & $\mathbf{A}$ & -38.872 & 571.8 & +0.2 & Apr. 17,1919 & $\mathbf{B}_{2}$ & -30.004 & 896.9 & +0.4 \\
\hline Nov. 29, 1918 & $\mathbf{A}$ & -38.872 & 571.7 & +0.1 & Apr. 16, 1919 & $\mathrm{~B}_{2}$ & -29.913 & 900.7 & +0.2 \\
\hline Mar. 18, 1919 & $\mathbf{B}_{\mathbf{3}}$ & -38.872 & 571.6 & 0.0 & Mar. 18, 1919 & $\mathbf{B}_{3}$ & -25.059 & 1134.2 & +0.1 \\
\hline Nov. 29,1918 & A & -38.872 & 571.7 & +0.1 & Mar. 15, 1919 & $\mathbf{B}_{1}$ & -25.050 & 1134.7 & +0.1 \\
\hline Do....... & $\mathbf{A}$ & -38.870 & 571.9 & +0.2 & May 2,1919 & $\mathbf{B}_{4}$ & -25.035 & 1136.0 & +0.6 \\
\hline Mar.15, 1919 & $\mathbf{B}_{1}$ & -38.867 & 572.0 & +0.2 & May 10, 1919 & $B_{4}$ & -25.019 & 1136.6 & +0.4 \\
\hline Nov. 29,1918 & A & -38.866 & 571.7 & -0.1 & Apr. 15,1919 & $\mathbf{B}_{2}$ & -25.018 & 1136.3 & 0.0 \\
\hline Mar. 15, 1919 & $\mathbf{B}_{1}$ & -38.865 & 572.1 . & +0.3 & Apr. 16,1919 & $\mathbf{B}_{2}$ & -25.005 & 1137.0 & +0.1 \\
\hline Mar.17, 1919 & $\mathbf{A}$ & -38.861 & 571.8 & -0.1 & Mar. 15, 1919 & $\mathbf{B}_{1}$ & -22.812 & 1257.3 & -0.1 \\
\hline Nov. 26,1918 & $\mathbf{A}$ & -37.643 & 610.2 & +0.4 & Do........ & $\mathbf{B}_{1}$ & -22.782 & 1259.2 & +0.1 \\
\hline Nov. 30,1918 & $\mathbf{A}$ & -36.781 & 637.9 & +0.1 & May 6,1919 & $\mathbf{B}_{4}$ & -20.012 & 1426.3 & +0.2 \\
\hline
\end{tabular}


TABLE 5.-Continued

\begin{tabular}{|c|c|c|c|c|c|c|c|c|c|}
\hline Date & Sample & $\begin{array}{c}\text { Obs. } \\
\text { temp., } \\
{ }^{\circ} \mathrm{C} \\
-\end{array}$ & $\begin{array}{l}\text { Press. } \\
\text { obs. by } \\
\text { manom- } \\
\text { eter, } \\
\text { mm Hg }\end{array}$ & $\begin{array}{c}\text { Devia- } \\
\text { tions } \\
\text { from } \\
\text { equa- } \\
\text { tion, } \\
\mathrm{mm} \mathrm{Hg}\end{array}$ & Date & Sample & $\begin{array}{l}\text { Obs. } \\
\text { temp., } \\
{ }^{\circ} \mathrm{C}\end{array}$ & $\begin{array}{l}\text { Press. } \\
\text { obs. by } \\
\text { manom- } \\
\text { eter, } \\
\text { mm Hg }\end{array}$ & $\begin{array}{l}\text { Devia- } \\
\text { tions } \\
\text { from } \\
\text { equa- } \\
\text { tion, } \\
\text { mm Hg }\end{array}$ \\
\hline May 7,1919 & $\mathbf{B}_{2}$ & -20.008 & 1426.9 & +0.6 & May 15, 1919 & $\mathbf{B}_{4}$ & 20.018 & 6432.5 & +0.2 \\
\hline Apr. 16,1919 & $\mathbf{B}_{2}$ & -20.005 & 1426.6 & +0.1 & May 16,1919 & $\mathrm{~B}_{4} \mathrm{~B}_{2}$ & 20.020 & 6432.2 & -0.5 \\
\hline Apr. 15,1919 & $\mathbf{B}_{2}$ & -20.004 & 1426.2 & -0.4 & May 15,1919 & $\mathbf{B}_{4}$ & 25.016 & 7525.1 & +0.8 \\
\hline May 2,1919 & $\mathbf{B}_{4}$ & -20.002 & 1427.3 & +0.6 & May 17,1919 & $\mathrm{~B}_{4} \mathrm{~B}_{2}$ & 25.176 & 7561.9 & +0.4 \\
\hline Do....... & $\mathrm{B}_{4}$ & -15.046 & 1769.8 & +0.8 & & & & & \\
\hline May 7,1919 & $\mathbf{B}_{2}$ & -15.025 & 1770.9 & +0.3 & & & & & \\
\hline Apr. 16,1919 & $\mathbf{B}_{2}$ & -15.020 & 1770.9 & 0.0 & & & & & \\
\hline Apr. 17,1919 & $\mathbf{B}_{2}$ & -15.003 & 1772.5 & +0.3 & & & & & \\
\hline May 6,1919 & $\mathbf{B}_{4}$ & -15.002 & 1772.6 & +0.3 & Mar. 22, 1919 & $\mathrm{C}_{2}$ & 15.120 & 5485.5 & +1.5 \\
\hline Do....... & $\mathrm{B}_{4}$ & -10.024 & 2179.9 & +0.6 & Mar. 26, 1919 & $\mathrm{C}_{2}$ & 19.999 & 6427.4 & -1.0 \\
\hline May 7,1919 & $B_{2}$ & -10.020 & 2179.8 & +0.2 & Do...... & $\mathrm{C}_{2}$ & 24.981 & 7515.1 & -1.2 \\
\hline May 2,1919 & $\mathbf{B}_{4}$ & -10.010 & 2181.4 & +0.9 & Do...... & $\mathrm{C}_{2}$ & 25.081 & 7538.4 & -0.7 \\
\hline Apr. 16,1919 & $\mathbf{B}_{2}$ & -10.009 & 2180.7 & +0.1 & May 19,1919 & $\mathrm{C}_{1}$ & 29.936 & 8735.9 & +3.5 \\
\hline Apr. 15,1919 & $\mathbf{B}_{\mathbf{2}}$ & -9.999 & 2180.5 & -0.9 & Apr. 1,1919 & $\mathrm{C}_{2}$ & 30.002 & 8749.8 & +0.2 \\
\hline Apr. 16, 1919 & $\mathbf{B}_{2}$ & -5.061 & 2654.1 & -1.1 & Do...... & $\mathrm{C}_{2}$ & 35.058 & 10137.0 & -4.4 \\
\hline May 3,1919 & $\mathbf{B}_{4}$ & -5.021 & 2659.8 & +0.4 & May 20,1919 & $\mathrm{C}_{1}$ & 35.022 & 10133.3 & +2.5 \\
\hline Apr. 17,1919 & $\mathbf{B}_{2}$ & -5.016 & 2659.7 & -0.2 & May 23,1919 & $\mathbf{C}_{1}$ & 39.928 & 11637.8 & +3.0 \\
\hline May 6,1919 & $\mathrm{~B}_{4}$ & -5.014 & 2660.2 & +0.1 & Do...... & $\mathrm{C}_{1}$ & 39.928 & 11636.6 & +1.8 \\
\hline May 7,1919 & $\mathbf{B}_{2}$ & -5.010 & 2660.3 & -0.2 & May 20,1919 & $\mathrm{C}_{1}$ & 39.995 & 11661.5 & +5.0 \\
\hline May 3,1919 & $\mathrm{~B}_{4}$ & -5.005 & 2661.7 & +0.7 & Mar. 31, 1919 & $\mathrm{C}_{2}$ & 44.919 & 13332.7 & +0.5 \\
\hline Apr. 17,1919 & $\mathbf{B}_{2}$ & -0.003 & 3220.7 & -0.1 & Apr. 2,1919 & $\mathrm{C}_{2}$ & 44.965 & 13348.7 & 0.0 \\
\hline Apr. 15,1919 & $\mathbf{B}_{2}$ & 0.000 & 3220.5 & -0.3 & May 20, 1919 & $\mathrm{C}_{1}$ & 45.071 & 13388.9 & +2.3 \\
\hline Apr. 16, 1919 & $\mathbf{B}_{2}$ & 0.000 & 3220.8 & 0.0 & May 23,1919 & $\mathrm{C}_{1}$ & 50.036 & 15262.3 & +2.6 \\
\hline Apr. 17,1919 & $\mathbf{B}_{2}$ & 0.000 & 3220.7 & -0.1 & Mar. 31, 1919 & $\mathrm{C}_{2}$ & 50.083 & 15274.1 & -4.2 \\
\hline May 3,1919 & $\mathbf{B}_{4}$ & 0.000 & 3220.4 & -0.4 & May 20,1919 & $\mathrm{C}_{1}$ & 50.117 & 15293.0 & +1.2 \\
\hline May 6,1919 & $\mathbf{B}_{4}$ & 0.000 & 3221.2 & +0.4 & May 24, 1919 & $\mathrm{C}_{1}$ & 55.004 & 17327.0 & +2.1 \\
\hline May 7,1919 & $\mathbf{B}_{4}$ & 0.000 & 3220.8 & 0.0 & May 27, 1919 & $C_{1}$ & 60.057 & 19632.1 & -1.5 \\
\hline Do...... & $\mathrm{B}_{4}$ & 0.000 & 3221.2 & +0.4 & Do...... & $\mathrm{C}_{1}$ & 60.062 & 19635.6 & -0.4 \\
\hline May 14, 1919 & $\mathrm{~B}_{4}$ & +5.022 & 3871.5 & +0.4 & Do...... & $\mathrm{C}_{1}$ & 60.062 & 19639.1 & +3.1 \\
\hline May 15, 1919 & $\mathrm{~B}_{4}$ & 5.022 & 3870.3 & -0.8 & Do..... & $\mathrm{C}_{1}$ & 60.060 & 19632.4 & -2.7 \\
\hline May 16, 1919 & $\mathrm{~B}_{1} \mathrm{~B}_{2}$ & 4.974 & 3864.3 & -0.1 & Do.:... & $\mathrm{C}_{1}$ & 60.066 & 19638.1 & +0.2 \\
\hline Do...... & $\mathrm{B}_{4} \mathrm{~B}_{2}$ & 9.994 & 4610.9 & -0.3 & Do..... & $\mathrm{C}_{1}$ & 65.051 & 22136.7 & +1.6 \\
\hline May 15, 1919 & $\mathbf{B}_{4}$ & 10.021 & 4615.4 & -0.1 & Do...... & $C_{i}$ & 65.059 & 22139.6 & +0.3 \\
\hline May 14,1919 & $\mathbf{B}_{4}$ & 10.035 & 4618.3 & +0.6 & Do..... & $\mathrm{C}_{1}$ & 65.063 & 22140.1 & -1.2 \\
\hline May 16, 1919 & $\mathrm{~B}_{4} \mathrm{~B}_{2}$ & 15.008 & 5463.3 & -0.5 & May 28,1919 & $\mathrm{C}_{1}$ & 70.011 & 24843.5 & -4.6 \\
\hline May 15, 1919 & $\mathbf{B}_{4}$ & 15.159 & 5491.3 & 0.0 & Do...... & $\mathrm{C}_{1}$ & 70.011 & 24842.6 & -5.5 \\
\hline
\end{tabular}

It may be noted from the above table of results that four values of the vapor pressure of ammonia may be obtained which are independent of the temperature scale employed. These are at the temperature of (I) the melting point of ice, (2) the freezing point of pure mercury, (3) the triple point of ammonia, and (4) the normal sublimation point of carbon dioxide. The corresponding vapor pressures of ammonia observed at these temperatures are (I) $3220.8 \mathrm{~mm}$, the mean of 7 experiments; (2) $57 \mathrm{I} .8 \mathrm{~mm}$, the mean of 14 experiments in which the bulb containing ammonia 
was immersed in freezing mercury; (3) $44.9 \mathrm{~mm}$, the mean of 2 experiments with the three phases solid, liquid, and vapor present; and (4) $42.2 \mathrm{~mm}$, the mean of 2 experiments with subcooled liquid ammonia.

The mean of the $\mathrm{I} 7$ observations taken within $0.1^{\circ} \mathrm{C}$ of the normal boiling point of ammonia with 6 different samples and corrected to $760 \mathrm{~mm}$ pressure gives the value $-33.354^{\circ} \mathrm{C}$.

\section{DETERMINATION OF THE NORIMAL BOILING POINT BY THE DYNAMIC METHOD}

In order to check the measurements of the normal boiling point of ammonia by the static method, a direct determination

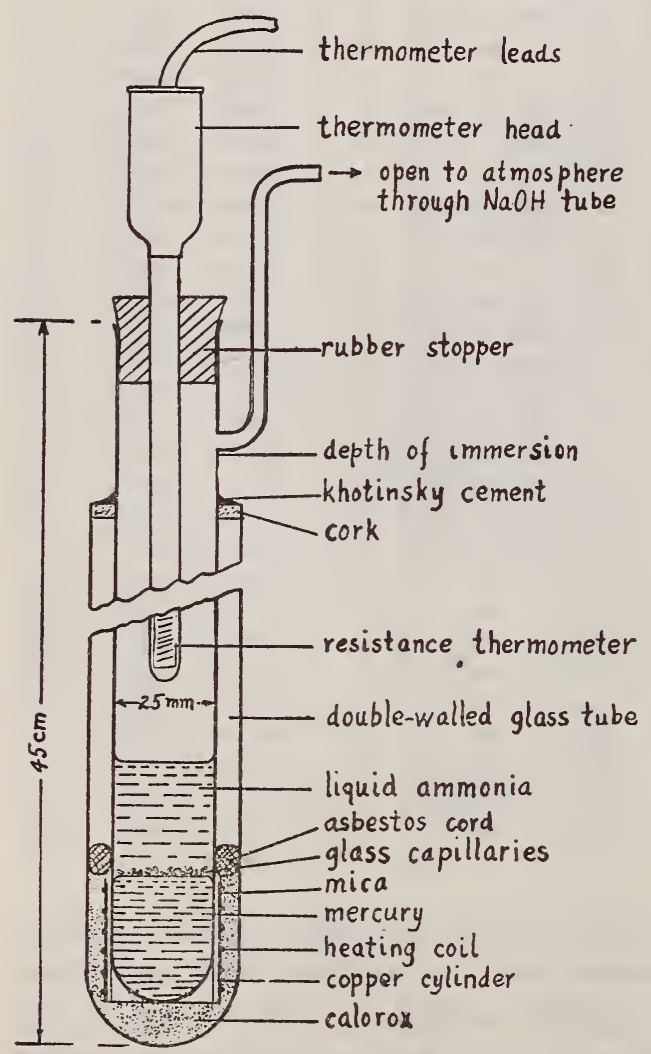

FIG. 8.-Normal boiling point apparatus was undertaken by the dynamic method analogous to the ordinary method of measuring steam points.

The apparatus used consisted of two concentric tubes of pyrex glass cemented together to form a double-walled vessel, as shown in Fig. 8. About $20 \mathrm{cc}$ of pure mercury and a large number of small glass capillaries were placed in the bottom of the inner tube to promote uniform boiling. A rubber stopper in the open end served to hold the platinum resistance thermometer in place, and al. lowedit to be moved upand down. After a thorough cleaning the apparatus was placed in a thermoregulated bath, evacuated and cooled below the normal boiling point of ammonia. Commercial ammonia of high purity contained in a small cylinder was then distilled into the apparatus through a sodium hydroxide drying tube. Chemical tests made upon this commercial sample indicated less than o.or per cent solid impurities (residue on evapora- 
tion), o.or per cent volatile carbon compounds, and 0.03 per cent water.

TABLE 6.-Determination of the Normal Boiling Point by the Dynamic Method

\begin{tabular}{c|c|c|c|c|c|c|c}
\hline Date & $\begin{array}{c}\text { Bath } \\
\text { temp., } \\
{ }^{\circ} \mathrm{C}\end{array}$ & $\begin{array}{c}\text { Heating } \\
\text { current, } \\
\text { amp. }\end{array}$ & $\begin{array}{c}\text { Height } \\
\text { of therm. } \\
\text { above } \\
\text { liquid, } \\
\text { cm }\end{array}$ & $\begin{array}{c}\text { Depth } \\
\text { of liquid } \\
\text { cm }\end{array}$ & $\begin{array}{c}\text { Baro. rdg. } \\
\text { reduced to } \\
0^{\circ} \text { C. \& st. gr. }\end{array}$ & Temp., ${ }^{\circ}$ Cobs. & Normal boil- \\
ing point, ${ }^{\circ}$ C
\end{tabular}

$a$ Very irregular boiling; observations taken without the addition of mercury.

$b$ Thermometer immersed.

$c$ Not included in mean.

The results of observations taken under various experimental conditions are shown in Table 6 . The thermometer was placed at different heights above the boiling liquid as the test of a sufficiently high condensation line to produce uniform temperature. In one instance the bulb of the resistance thermometer was completely immersed in the boiling liquid and a rise in temperature of about $0.05^{\circ} \mathrm{C}$ was observed. The mean of $\mathrm{I} 7$ observations corrected to temperatures corresponding to $760 \mathrm{~mm}$ pressure gives the value $-33.34 \mathrm{I}^{\circ} \mathrm{C}$ for the normal boiling point.

\section{FORM OF EMPIRICAL EQUATIONS}

Numerous empirical equations of widely different forms have been proposed in the past century to represent vapor pressures as a function of temperature. Attempts have been made to establish this functional relationship upon a semirational basis by introducing approximations into the Clapeyron equation and then integrating. The Rankine-Dupré formula

$$
\log p=A+B / \theta+C \log \theta
$$


was deduced in this manner, and found to represent the experimental results for a large number of substances with a fair degree of approximation. Similarly, Nernst deduced an equation of the form

$$
\log p=A+B / \theta+C \log \theta+D \theta,
$$

which represents very accurately pressure measurements within a limited region, particularly in the region below the normal boiling point. Quite recently Brunelli ${ }^{36}$ has gone one step farther and proposed an empirical equation of the form

$$
\log p=A+B / \theta+C \log \theta+D \theta+E \theta^{2}
$$

$\mathrm{He}$ has evaluated the constants in this equation for water, and compared the calculated values of vapor pressure with those determined by experiment, which are more accurately known, perhaps, than for any other substance. The agreement throughout the range from $0^{\circ} \mathrm{C}$ to the critical temperature is remarkably good. A similar empirical equation of the form

$$
\log p=A+B / \theta+C \theta+D \theta^{2}+E \theta^{3}
$$

has been used by Keyes and Brownlee to represent their experimental results on ammonia.

Equations of the forms (I) and (2) were found to represent very closely the results of the present experimental work, and also Cardoso and Giltay's ${ }^{37}$ determination of the critical data. An equation of the form

$$
\log p=A+B / \theta+C / \theta^{2}+D / \theta^{3}
$$

was tried, but did not represent the data satisfactorily.

\section{DISCUSSION OF RESULTS}

The results of the measurements may be expressed equally well by means of either of the following empirical equations:

$$
\begin{aligned}
\log _{10} p=30.2568 \mathrm{I} 8-\frac{1914.9569}{\theta} & -8.4598324 \log _{10} \theta+2.39309 \times 10^{-3} \theta \\
& +2.955214 \times 10^{-6} \theta^{2}
\end{aligned}
$$

and

$$
\begin{aligned}
\log _{10} p=\mathrm{I} 2.465400-\frac{\mathrm{I} 648.6068}{\theta} & -0.01638646 \theta+2.403267 \times 10^{-5} \theta^{2} \\
& -1.168708 \times 10^{-8} \theta^{3}
\end{aligned}
$$

which were made to satisfy Cardoso and Giltay's critical data, $p_{\mathrm{c}}=85348 \mathrm{~mm}$ and $\theta_{\mathrm{c}}=132.9^{\circ} \mathrm{C}$. In these equations $p$ and $\theta$ are 
expressed in $\mathrm{mm}$ of mercury and degrees absolute, respectively $\left({ }^{\circ} \mathrm{Abs} .={ }^{\circ} \mathrm{C}+273 \cdot \mathrm{I}\right)$.

The deviations of the individual measurements in millimeters of mercury from values computed by these equations are shown in Table 5. In the 122 measurements made with the single manometers and the open mercury manometer in the interval from $-78^{\circ} \mathrm{C}$ to $+25^{\circ} \mathrm{C}$, inclusive, the maximum deviation is I.I $\mathrm{mm}$ and the average deviation is $0.3 \mathrm{~mm}$, which is within the limit of error of actual pressure observation. In the 28 measurements made in the interval $+15^{\circ} \mathrm{C}$ to $+70^{\circ} \mathrm{C}$, inclusive, with the piston gage, the maximum deviation is $5.5 \mathrm{~mm}$, at the highest temperature, and the average deviation is $2.1 \mathrm{~mm}$, or on the average about 2 parts in 1000 in the pressure. This agreement is very satisfactory when consideration is given to the precision of the piston gage and also to the effect of temperature on the pressure; for example, an error of $0.0 \mathrm{I}^{\circ} \mathrm{C}$ in the temperature is equivalent in this range to from 2 to $6 \mathrm{~mm}$ in the pressure.

The majority of the measurements, except those below the normal boiling point, were purposely taken at approximately $5^{\circ}$ intervals, within a tenth of a degree. The rate of change of vapor pressure with temperature, computed from the above equations, was used to correct the individual measurements to the integral degrees. The means of these corrected measurements are given in Table 7 and compared with the calculated values. The deviations, expressed in degrees Centigrade, indicate the good agreement between observed and calculated values.

TABLE 7.-Deviations in Degrees Centigrade of Mean Observed Pressures from Authors' Equations

\begin{tabular}{|c|c|c|c|c|c|c|c|c|c|}
\hline${ }^{\circ}{ }^{t_{1}} \mathbf{C}$ & $\begin{array}{l}\text { Num- } \\
\text { ber of } \\
\text { obs. }\end{array}$ & $\begin{array}{l}\text { Mean } \\
p \text { obs., } \\
\text { mm Hg }\end{array}$ & $\begin{array}{l}t \text { calc. } \\
{ }^{\circ} \mathrm{C}\end{array}$ & $\begin{array}{c}t-t \text { calc. } \\
\text { in } 0.001^{\circ} \\
{ }^{\circ} \mathrm{C}\end{array}$ & ${ }^{t}{ }^{\prime} \mathrm{C}$ & $\begin{array}{l}\text { Num- } \\
\text { ber of } \\
\text { obs. }\end{array}$ & $\begin{array}{c}\text { Mean } \\
\text { p obs., } \\
\text { mm Hg }\end{array}$ & $\begin{array}{l}t \text { calc., } \\
{ }^{\circ} \mathrm{C}\end{array}$ & $\begin{array}{c}t-t \text { calc., } \\
\text { in } 0.001^{\circ} \\
{ }^{\circ} \mathrm{C}\end{array}$ \\
\hline-78 & 3 & 44.00 & -78.076 & +76 & +5 & 3 & 3867.9 & +4.999 & +1 \\
\hline-64 & 2 & 125.29 & -64.016 & +16 & 10 & 3 & 4612.1 & 10.000 & 0 \\
\hline-51 & 4 & 289.43 & -50.966 & -34 & 15 & 3 & 5462.6 & 14.999 & +1 \\
\hline-48 & 4 & 345.03 & -47.983 & -17 & 20 & 3 & 6428.2 & 19.998 & +2 \\
\hline-44 & 7 & 432.98 & -43.987 & -13 & 25 & 4 & 7520.5 & 25.000 & 0 \\
\hline-40 & 2 & 538.58 & -39.990 & -10 & 30 & 2 & 8750.9 & 30.007 & -7 \\
\hline-38.870 & 14 & 571.77 & -38.867 & -3 & 35 & 2 & 10123.5 & 35.003 & +3 \\
\hline-33.354 & 17 & 760.00 & -33.347 & -7 & 40 & 3 & 11661.4 & 40.010 & -10 \\
\hline-30 & 6 & 897.2 & -29.989 & -11 & 45 & 3 & 13362.3 & 45.003 & -3 \\
\hline-25 & 6 & 1137.4 & -24.995 & -5 & 50 & 3 & 15245.4 & 50.000 & 0 \\
\hline-20 & 5 & 1427.0 & -19.997 & -3 & 55 & 1 & 17325.3 & 55.005 & -5 \\
\hline-15 & 5 & 1772.8 & -14.995 & -5 & 60 & 5 & 19606.1 & 59.999 & +1 \\
\hline-10 & 5 & 2181.6 & -9.998 & -2 & 65 & 3 & 22108.5 & 65.000 & 0 \\
\hline-5 & 6 & 2661.5 & -5.000 & 0 & 70 & 2 & 24836.8 & 69.991 & +9 \\
\hline 0 & 8 & 3220.8 & 0.000 & 0 & & & & & \\
\hline
\end{tabular}


The remarkable reproducibility of the observed pressures at the normal boiling point and at the ice point $\left(0^{\circ} \mathrm{C}\right)$ on different days and with various samples seems to preclude the possibility of any systematic error due to the sample, which was not obscured by errors of measurement, or, in other words, that the material used was of a high degree of purity. The agreement between the pressure observed by means of the open mercury manometer and the piston gage in the interval within which they overlap indicates that no appreciable systematic error resulted from the use of the latter. Additional confirmation of this is furnished in the careful calibration of the piston gage against the open mercury manometer.

The slope of the vapor pressure-temperature curve for ammonia is expressed equally well by the differentiation of either of the above equations, as follows:

$$
\begin{array}{r}
\frac{d p}{d \theta}=2.3025^{8} \frac{p}{\theta}\left(\frac{\text { I } 914.9569}{\theta}-8.4598324 \log _{10} e-2.39309 \times 10^{-3} \theta\right. \\
\left.+5.910428 \times 10^{-6} \theta^{2}\right)
\end{array}
$$

and

$$
\begin{aligned}
& \frac{d p}{d \theta}=2.3025^{8} \frac{p}{\theta}\left(\frac{1648.6068}{\theta}-0.01638646+4.80655^{2} \times 1 \mathrm{IO}^{-5} \theta^{2}\right. \\
& \left.-3.506 \mathrm{1} 24 \times 1 \mathrm{IO}^{-8} \theta^{3}\right)
\end{aligned}
$$

where $\frac{d p}{d \theta}$ and $p$ are in millimeters of mercury per degree centigrade and millimeters of mercury, respectively, and $\theta$ in degrees absolute.

The estimated errors in the values of $\frac{d p}{d \theta}$ thus obtained are, from consideration of Table 7 , about $\mathrm{I}$ part in 200 in the range $-80^{\circ}$ to $-50^{\circ} \mathrm{C}$, I part in 500 in the range $-50^{\circ}$ to $-30^{\circ} \mathrm{C}$ and I part in 1000 in the range $-30^{\circ}$ to $+70^{\circ} \mathrm{C}$.

The results of the measurements of the normal boiling point by the static method, which give a mean value of $-33.354^{\circ} \mathrm{C}$, are in fair agreement with the measurements by the dynamic method, whose mean is $-33.34 \mathrm{I}^{\circ} \mathrm{C}$. The normal boiling point is, therefore, taken as $-33.35^{\circ} \mathrm{C}$.

The present work has been carried out with very pure samples of ammonia. The question immediately arises in the practical application of the results as to how much the results would be affected by the impurities commonly found in commercial samples. 
The normal boiling point found by the dynamic method, in which the temperature of the condensing vapor is measured, would be very little affected by these impurities, while a satisfactory determination by the static method with commercial samples is practically impossible. This illustrates the fact that the results obtained in measurements with impure materials may depend more upon the method chosen than upon the purity, and that refined physical measurements should be attempted only with the purest materials. The impurities present in commercial materials may prevent the engineers being able to utilize fully the accuracy of the physical data, yet the data for pure material are at least as likely to be representative of a given commercial sample as data on impure material. As shown in the normal boiling point determinations, the properties of commercial samples under proper conditions may differ very slightly from those of a pure material.

In conclusion, the authors wish to acknowledge their indebtedness to Dr. C. W. Waidner, E. F. Mueller, and E. C. McKelvy, of this Bureau, for many valuable suggestions during the progress of this investigation.

\section{SUMMARY}

The previous measurements of the vapor pressure of ammonia are briefly reviewed and tabulated.

A detailed description is given of the apparatus and method employed in the present measurements throughout the temperature interval $-78^{\circ}$ to $+70^{\circ} \mathrm{C}$.

Seven samples of thoroughly purified ammonia were used. Special tests showed less than I part in Ioo ooo by volume of noncondensing gases present and less than o.or per cent, by weight, of other impurities. The methods of purification and filling of manometers are briefly described.

The phenomenon of hysteresis was observed near the normal boiling point of ammonia with a commercial sample containing a small amount of air, which indicated the necessity of very complete removal of dissolved gases for any accurate measurements of vapor pressure by the static method. Lags in coming, to equilibrium were encountered and studied in order to determine the most advantageous procedure in establishing equilibrium.

The normal boiling point of ammonia was determined by the static and also the dynamic method, the mean of the results by the two methods being $-33.35^{\circ} \mathrm{C}$. 
Two empirical equations were found to represent closely the results in the temperature range covered experimentally and also the latest determination of the critical data for ammonia. The results of 122 measurements in the interval $-78^{\circ}$ to $+25^{\circ} \mathrm{C}$ made with direct observations of mercury columns agree with the empirical equations within I mm of mercury. The results of 28 measurements in the interval $+15^{\circ}$ to $+70^{\circ} \mathrm{C}$, made with an accurately calibrated piston gage, agree with the empirical equations within about $3 \mathrm{~mm}$ of mercury.

As a final result, the vapor pressure of ammonia is expressed in the range $-80^{\circ}$ to $+70^{\circ} \mathrm{C}$ by either of the following equations:

$$
\begin{gathered}
\log _{10} p=30.2568 \mathrm{I} 8-\frac{\mathrm{I} 9 \mathrm{I} 4.9569}{\theta}-8.4598324 \log _{10} \theta+2.39309 \times 1 \mathrm{IO}^{-3} \theta \\
+2.9552 \mathrm{I} 4 \times \mathrm{IO}^{-8} \theta^{2} . \\
\log _{10} p=\mathrm{I} 2.465400-\frac{\mathrm{I} 648.6068}{\theta}-0.01638646 \theta+2.403267 \times 1 \mathrm{IO}^{-5} \theta^{2} \\
-\mathrm{I} . \mathrm{I} 68708 \times 10^{-8} \theta^{3}
\end{gathered}
$$

where $p$ is expressed in millimeters of mercury, and $\theta$ in degrees absolute $\left({ }^{\circ} \mathrm{Abs} .={ }^{\circ} \mathrm{C}+273 \cdot \mathrm{I}\right)$. The slope of the vapor pressuretemperature curve is obtained by differentiation of either of the above equations. 


\section{APPENDIXES}

APPENDIX 1.-Vapor Pressure of Ammonia

[Millimeters of mercury at $0^{\circ} \mathrm{C}$ and $\mathrm{g}=980.665$ ]

\begin{tabular}{|c|c|c|c|c|c|c|c|c|c|c|}
\hline${ }^{\circ} \mathrm{C}$ & 0 & 1 & 2 & 3 & 4 & 5 & 6 & 7 & 8 & 9 \\
\hline-80 & 37.6 & & & & & & & & & \\
\hline-70 & 81.9 & 76.1 & 70.6 & 65.5 & 60.6 & 56.1 & 51.9 & 48.0 & 44.3 & 40.8 \\
\hline-60 & 164.2 & 153.7 & 143.7 & 134.3 & 125.4 & 117.1 & 109. 2 & 101.8 & 94.7 & 88.1 \\
\hline-50 & 306.6 & 288.8 & 272.0 & 255.9 & 240.7 & 226.2 & 212.5 & 199.4 & 187.0 & 175.3 \\
\hline-40 & 538.3 & 510.1 & 483.1 & 457.3 & 432.7 & 409.1 & 386.6 & 365.2 & 344.7 & 325.2 \\
\hline-30 & 896.7 & 853.9 & 812.8 & 773.3 & 735.4 & 699.0 & 664.1 & 630.6 & 598.5 & 567.8 \\
\hline-20 & 1426.8 & 1364.6 & 1304.6 & 1246.8 & 1191.0 & 1137.2 & 1085.3 & 1035.4 & 987.4 & 941.2 \\
\hline-10 & 2181.4 & 2094.2 & 2009.7 & 1928.0 & 1848.9 & 1772.4 & 1698.5 & 1627.0 & 1557.9 & 1491.2 \\
\hline-0 & 3221.0 & 3102.2 & 2987.0 & 2875.2 & 2766.7 & 2661.5 & 2559.4 & 2460.4 & 2364.5 & 2271.5 \\
\hline+0 & 3221.0 & 3343.0 & 3468.5 & 3598.0 & 3731.0 & 3868.0 & 4009.0 & 4153.5 & 4302.5 & 4455.0 \\
\hline 10 & 4612.0 & 4773.5 & 4939.0 & 5109.0 & 5283.5 & 5462.5 & 5646.0 & 5834.5 & 6027.5 & 6225.5 \\
\hline 20 & 6428.5 & 6636.5 & 6849.5 & 7068.0 & 7291.5 & 7520.5 & 7755.0 & 7995.0 & 8240.5 & 8492.0 \\
\hline 30 & 8749.0 & 9012.0 & 9281.0 & 9556.0 & 9837.0 & 10124.0 & 10418.0 & 10718.0 & 11025.0 & 11338.0 \\
\hline 40 & 11658.0 & 11985.0 & 12318.0 & 12659.0 & 13006.0 & 13361.0 & 13723.0 & 14092.0 & 14469.0 & 14853.0 \\
\hline 50 & 15245.0 & 15645.0 & 16052.0 & 16467.0 & 16891.0 & 17323.0 & 17763.0 & 18211.0 & 18667.0 & 19132.0 \\
\hline 60 & 19606.0 & 20089.0 & 20580.0 & 21080.0 & 21589.0 & 22108.0 & 22636.0 & 23173.0 & 23720.0 & 24276.0 \\
\hline 70 & 24842.0 & & & & & & & & & \\
\hline
\end{tabular}

[Atmospheres (1 atmos. $=760 \mathrm{~mm}$ mercury)]

\begin{tabular}{|c|c|c|c|c|c|c|c|c|c|c|}
\hline${ }^{\circ} \mathrm{C}$ & 0 & 1 & 2 & 3 & 4 & 5 & 6 & 7 & 8 & 9 \\
\hline-80 & 0.0495 & & & & n..... & & & & & \\
\hline-70 & .1078 & 0.1001 & 0.0929 & 0.0861 & 0.0797 & 0.0738 & 0.0683 & 0.0631 & 0.0582 & 0.0537 \\
\hline-60 & .2161 & .2022 & .1891 & .1767 & .1651 & .1541 & .1437 & .1339 & .1246 & .1159 \\
\hline-50 & .4034 & .3800 & .3578 & .3367 & .3167 & .2977 & .2796 & .2624 & .2461 & .2307 \\
\hline-40 & .7083 & .6712 & .6357 & .6017 & .5693 & .5383 & .5087 & .4805 & .4536 & .4279 \\
\hline-30 & 1. 1799 & 1. 1236 & 1.0695 & 1. 0175 & .9676 & .9197 & .8738 & .8297 & .7875 & .7471 \\
\hline-20 & 1.8774 & 1. 7956 & 1. 7166 & 1.6405 & 1. 5671 & 1.4963 & 1. 4281 & 1. 3624 & 1. 2992 & 1. 2384 \\
\hline-10 & 2.8703 & 2. 7555 & 2. 6443 & 2. 5368 & 2. 4328 & 2. 3322 & 2. 2349 & 2. 1408 & 2. 0499 & 1.9621 \\
\hline-0 & 4. 2380 & 4.0818 & 3. 9303 & 3. 7832 & 3. 6405 & 3.5020 & 3. 3677 & 3. 2375 & 3. 1112 & 2.9888 \\
\hline+0 & 4. 2380 & 4. 3985 & 4. 5640 & 4. 7340 & 4. 9090 & 5.0895 & 5. 2750 & 5.4655 & 5.6610 & 5.8620 \\
\hline 10 & 6.0685 & 6. 2805 & 6.4985 & 6.7225 & 6. 9520 & 7.1875 & 7.4290 & 7.6770 & 7.9310 & 8.1915 \\
\hline 20 & 8.4585 & 8.7320 & 9.0125 & 9. 3000 & 9.5940 & 9.8955 & 10.2040 & 10.5195 & 10.8430 & 11.1735 \\
\hline 30 & 11.512 & 11.858 & 12. 212 & 12. 574 & 12.943 & 13.321 & 13. 708 & 14. 103 & 14.507 & 14.919 \\
\hline 40 & 15. 339 & 15. 770 & 16. 209 & 16.656 & 17.113 & 17.580 & 18.056 & 18. 542 & 19.038 & 19. 543 \\
\hline 50 & 20.059 & 20.585 & 21.121 & 21.667 & 22.224 & 22. 793 & 23. 372 & 23.962 & 24.562 & 25.174 \\
\hline 60 & 25. 797 & 26.432 & 27.079 & 27.737 & 28.407 & 29.089 & 29.784 & 30.491 & 31. 211 & 31.942 \\
\hline 70 & 32.687 & & 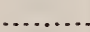 & & 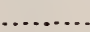 & & 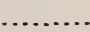 & & & \\
\hline
\end{tabular}


APPENDIX 2.-Vapor Pressure of Ammonia

[Pounds per square inch ( $1 \mathrm{lb} . /$ in. ${ }^{2}=51.713 \mathrm{~mm} \mathrm{Hg}$ )]

\begin{tabular}{|c|c|c|c|c|c|c|c|c|c|c|}
\hline${ }^{\circ} \mathrm{F}$ & 0 & 1 & 2 & 3 & 4 & 5 & 6 & 7 & 8 & 9 \\
\hline-110 & 0.796 & 0.761 & 0.727 & ....... & ....... & . & ........ & 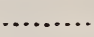 & ........ & ....... \\
\hline-100 & 1. 234 & 1.183 & 1.133 & 1.085 & 1.039 & 0.995 & 0.952 & 0.911 & 0.871 & 0.833 \\
\hline-90 & 1.861 & 1.788 & 1.718 & 1.650 & 1. 584 & 1.520 & 1.458 & 1.399 & 1. 342 & 1.287 \\
\hline-80 & 2.740 & 2.639 & 2. 541 & 2.446 & 2. 354 & 2. 265 & 2.179 & 2.095 & 2. 014 & 1.936 \\
\hline-70 & 3.939 & 3. 802 & 3.669 & 3. 540 & 3.415 & 3.293 & 3.175 & 3. 061 & 2. 951 & 2. 844 \\
\hline-60 & 5.548 & 5.366 & 5.189 & 5.017 & 4.849 & 4.686 & 4.528 & 4. 374 & 4. 225 & 4.080 \\
\hline-50 & 7.667 & 7.429 & 7.197 & 6.971 & 6.751 & 6.537 & 6.329 & 6.126 & 5.928 & 5.735 \\
\hline-40 & 10.409 & 10.104 & 9.805 & 9.513 & 9.229 & 8.952 & 8.682 & 8.419 & 8. 162 & 7.911 \\
\hline-30 & 13.905 & 13.517 & 13.138 & 12. 768 & 12.407 & 12.054 & 11.709 & 11.372 & 11.043 & 10. 722 \\
\hline-20 & 18.297 & 17.813 & 17.339 & 16.876 & 16.423 & 15.979 & 15.545 & 15.121 & 14. 707 & 14.302 \\
\hline-10 & 23. 745 & 23.148 & 22.563 & 21.990 & 21.429 & 20.879 & 20.341 & 19.813 & 19. 297 & 18.792 \\
\hline-0 & 30.420 & 29.691 & 28.977 & 28.277 & 27.591 & 26.917 & 26. 257 & 25.610 & 24.976 & 24. 354 \\
\hline+0 & 30.420 & 31.160 & 31.915 & 32.690 & 33.475 & 34.275 & 35.090 & 35.920 & 36.765 & 37.630 \\
\hline 10 & 38.505 & 39.400 & 40.310 & 41.240 & 42.185 & 43.145 & 44.120 & 45.115 & 46.130 & 47.160 \\
\hline 20 & 48.210 & 49.275 & 50.360 & 51.465 & 52.590 & 53. 730 & 54.895 & 56.075 & 57.275 & 58.495 \\
\hline 30 & 59.74 & 61.00 & 62.28 & 63.58 & 64.91 & 66.26 & 67.62 & 69.01 & 70.43 & 71.86 \\
\hline 40 & 73.32 & 74.80 & 76.30 & 77.83 & 79.38 & 80.95 & 82.55 & 84.17 & 85.82 & 87.49 \\
\hline 50 & 89.19 & 90.91 & 92.66 & 94.43 & 96.23 & 98.05 & 99.91 & 101.79 & 103.69 & 105.63 \\
\hline 60 & 107.59 & 109. 58 & .111 .60 & 113.64 & 115.72 & 117.82 & 119.96 & 122.12 & 124.31 & 126.53 \\
\hline 70 & 128.79 & 131.07 & 133. 38 & 135.73 & 138. 11 & 140. 51 & 142.96 & 145.43 & 147.94 & 150.47 \\
\hline 80 & 153. 05 & 155.65 & 158.29 & 160.96 & 163.67 & 166.41 & 169.18 & 172.00 & 174.84 & 177.73 \\
\hline 90 & 180.65 & 183.60 & 186.59 & 189. 61 & 192.67 & 195. 77 & 198.91 & 202.08 & 205. 30 & 208.57 \\
\hline 100 & 211.86 & 215.20 & 218.57 & 221. 97 & 225.43 & 228.92 & 232.45 & 236.03 & 239.65 & 243.32 \\
\hline 110 & 247.02 & 250.75 & 254.54 & 258. 37 & 262.23 & 266.14 & 270.10 & 274.11 & 278.16 & 282.25 \\
\hline 120 & 286.39 & 290.57 & 294.80 & 299.08 & 303.40 & 307.77 & 312.18 & 316.65 & 321.16 & 325.72 \\
\hline 130 & 330.32 & 334.98 & 339.68 & 344.44 & 349.25 & 354.11 & 359.01 & 363.97 & 368.98 & 374.03 \\
\hline 140 & 379.13 & 384.29 & 389.51 & 394.77 & 400.09 & 405.47 & 410.90 & 416. 39 & 421.92 & 427.51 \\
\hline 150 & 433.16 & 438.86 & 444.62 & 450.44 & 456. 32 & 462.26 & 468.23 & 474.27 & 480.38 & ........ \\
\hline
\end{tabular}


APPENDIX 2-Continued

[Atmospheres ( 1 atmos. $=760 \mathrm{~mm}$ mercury)]

\begin{tabular}{|c|c|c|c|c|c|c|c|c|c|c|}
\hline$\circ \mathrm{F}$ & 0 & 1 & 2 & 3 & 4 & 5 & 6 & 7 & 8 & 9 \\
\hline-110 & 0.0542 & 0.0518 & 0.0495 & $\ldots \ldots$ & & $x^{2}-5=2=1$ & & & ........ & . . . . . \\
\hline-100 & .0840 & .0805 & .0771 & 0.0738 & 0.0707 & 0.0677 & 0.0648 & 0.0620 & 0.0593 & 0.0567 \\
\hline-90 & .1266 & .1217 & .1169 & .1123 & .1078 & .1035 & .0993 & .0953 & .0914 & .0876 \\
\hline-80 & .1865 & .1796 & .1729 & .1664 & .1602 & .1541 & .1482 & .1425 & .1370 & .1317 \\
\hline-70 & .2680 & .2587 & .2497 & .2409 & .2324 & .2241 & .2161 & .2083 & .2008 & .1935 \\
\hline-60 & .3775 & .3651 & .3531 & .3414 & .3300 & .3189 & .3081 & .2977 & .2875 & .2776 \\
\hline-50 & .5217 & .5055 & .4897 & .4744 & .4594 & .4448 & .4306 & .4168 & .4034 & .3903 \\
\hline-40 & .7083 & .6875 & .6672 & .6473 & .6280 & .6092 & .5908 & .5728 & .5553 & .5383 \\
\hline-30 & .9461 & .9197 & .8940 & .8688 & .8442 & .8202 & .7967 & .7738 & .7515 & .7296 \\
\hline-20 & 1. 2450 & 1. 2121 & 1. 1799 & 1. 1484 & 1. 1175 & 1.0873 & 1.0578 & 1. 0289 & 1.0007 & .9731 \\
\hline-10 & 1. 6157 & 1. 5751 & 1. 5353 & 1.4963 & 1. 4581 & 1.4207 & 1. 3841 & 1. 3482 & 1. 3131 & 1. 2787 \\
\hline-0 & $2.0698^{\prime}$ & 2.0203 & 1.9717 & 1.9241 & 1.8774 & 1.8316 & 1. 7867 & 1. 7426 & 1.6994 & 1. 6571 \\
\hline+0 & 2.0698 & 2.1203 & 2.1718 & 2. 2242 & 2. 2777 & 2. 3322 & 2. 3877 & 2. 4442 & 2.5017 & 2.5604 \\
\hline 10 & 2. 6202 & 2. 6810 & 2.7430 & 2. 8061 & 2. 8703 & 2. 9357 & 3.0022 & 3.0699 & 3.1388 & 3. 2089 \\
\hline 20 & 3. 2803 & 3. 3529 & 3. 4268 & 3.5020 & 3. 5784 & 3. 6561 & 3. 7351 & 3. 8155 & 3. 8972 & 3.9803 \\
\hline 30 & 4. .0647 & 4. 1507 & 4. 2380 & 4. 3265 & 4. 4165 & 4.5080 & 4. 6015 & 4. 6960 & 4. 7920 & 4.8895 \\
\hline 40 & 4.9890 & 5.0895 & 5.1915 & 5. 2955 & 5. 4010 & 5.5080 & 5. 6170 & 5.7275 & 5. 8395 & 5.9530 \\
\hline 50 & 6.0685 & 6. 1855 & 6.3045 & 6.4255 & 6.5480 & 6.6720 & 6. 7980 & 6.9260 & 7.0560 & 7.1875 \\
\hline 60 & 7. 3210 & 7.4560 & 7.5935 & 7.7330 & 7.8740 & 8.0170 & 8.1625 & 8. 3095 & 8.4585 & 8.6100 \\
\hline 70 & 8. 763 & 8.918 & 9.077 & 9.236 & 9.397 & 9.561 & 9.727 & 9.895 & 10.066 & 10.239 \\
\hline 80 & 10.414 & 10.591 & 10.770 & 10.952 & 11.137 & 11.323 & 11.512 & 11. 703 & 11.897 & 12.093 \\
\hline 90 & 12.292 & 12.492 & 12.696 & 12.902 & 13.110 & 13. 321 & 13.535 & 13. 751 & 13.970 & 14. 192 \\
\hline 100 & 14.416 & 14. 643 & 14.872 & 15.104 & 15. 339 & 15.577 & 15.817 & 16. 061 & 16. 307 & 16. 556 \\
\hline 110 & 16.808 & 17.062 & 17. 320 & 17.580 & 17.843 & 18.110 & 18. 379 & 18.651 & 18.926 & 19. 205 \\
\hline 120 & 19. 487 & 19. 772 & 20.059 & 20. 351 & 20.645 & 20.942 & 21. 242 & 21.546 & 21.853 & 22.163 \\
\hline 130 & 22.476 & 22. 793 & 23. 113 & 23. 437 & 23. 764 & 24.095 & 24.428 & 24.766 & 25.107 & 25.450 \\
\hline 140 & 25.797 & 26.149 & 26.504 & 26.862 & 27.224 & 27.589 & 27.959 & 28.333 & 28.709 & 29.089 \\
\hline 150 & 29.474 & 29.862 & 30.254 & 30.650 & 31.050 & 31.454 & 31.861 & 32.272 & 32. 687 & ;. \\
\hline
\end{tabular}

APPENDIX 3.-Rate of Change of Vapor Pressure with Temperature $\left(\frac{d p}{d \theta}\right)$ [Millimeters of mercury per degree centigrade]

\begin{tabular}{|c|c|c|c|c|c|c|c|c|c|c|}
\hline${ }^{\circ} \mathrm{C}$ & 0 & 1 & 2 & 3 & 4 & 5 & 6 & 7 & 8 & 9 \\
\hline-80 & 3.08 & & $\ldots \ldots$ & & ....... & . & ...... & ...... & $\ldots . .$. & $\ldots \ldots$ \\
\hline-70 & 6.02 & 5.66 & 5.31 & 4.98 & 4.66 & 4. 36 & 4.08 & 3. 81 & 3.55 & 3. 31 \\
\hline-60 & 10.81 & 10.23 & 9.67 & 9.14 & 8.63 & 8.14 & 7.67 & 7.22 & 6.80 & 6.40 \\
\hline-50 & 18.15 & 17.28 & 16.44 & 15.63 & 14.85 & 14.10 & 13. 38 & 12. 70 & 12.05 & 11.42 \\
\hline-40 & 28.82 & 27.58 & 26.38 & 25.22 & 24.10 & 23.02 & 21.98 & 20.97 & 20.00 & 19.06 \\
\hline-30 & 43.61 & 41.92 & 40.28 & 38.69 & 37.15 & 35.65 & 34.20 & 32.79 & 31.42 & 30.10 \\
\hline-20 & 63.29 & 61.08 & 58.93 & 56.83 & 54.78 & 52.78 & 50.84 & 48.95 & 47.12 & 45.34 \\
\hline-10 & 88.64 & 85.83 & 83.08 & 80.40 & 77.78 & 75.21 & 72.70 & 70.26 & 67.88 & 65.56 \\
\hline-0 & 120.35 & 116.90 & 113.49 & 110.14 & 106.86 & 103.66 & 100.53 & 97.46 & 94.45 & 91.51 \\
\hline+0 & 120.35 & 123.90 & 127.55 & 131.25 & 135.00 & 138.80 & 142.70 & 146.70 & 150.75 & 154.90 \\
\hline 10 & 159.10 & 163.40 & 167.75 & 172.20 & 176.70 & 181. 30 & 186.00 & 190.75 & 195.55 & 200.50 \\
\hline 20 & 205.50 & 210.55 & 215.70 & 220.95 & 226.30 & 231.70 & 237.20 & 242.80 & 248.50 & 254.25 \\
\hline 30 & 260.1 & 266.0 & 272.0 & 278.1 & 284.3 & 290.6 & 297.0 & 303.5 & 310.0 & 316.6 \\
\hline 40 & 323.3 & 330.1 & 337.0 & 344.0 & 351.1 & 358.3 & 365.6 & 373.0 & 380.5 & 388.1 \\
\hline 50 & 395.8 & 403.6 & 411.4 & 419.4 & 427.5 & 435.7 & 444.0 & 452.3 & 460.8 & 469.4 \\
\hline 60 & 478.1 & 486.9 & 495.8 & 504.8 & 513.9 & 523.1 & 532.4 & 541.8 & 551.3 & 561.0 \\
\hline 70 & 570.8 & & & & 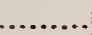 & 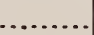 & & & & \\
\hline
\end{tabular}

WASHINGTON, November I2, I9I9. 



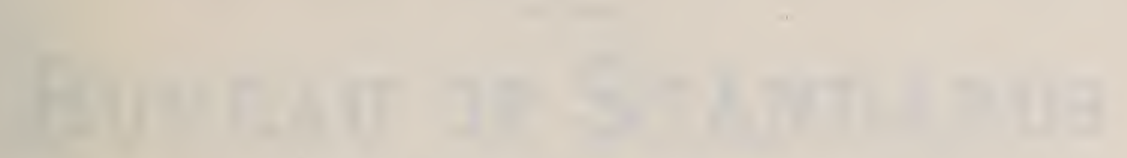



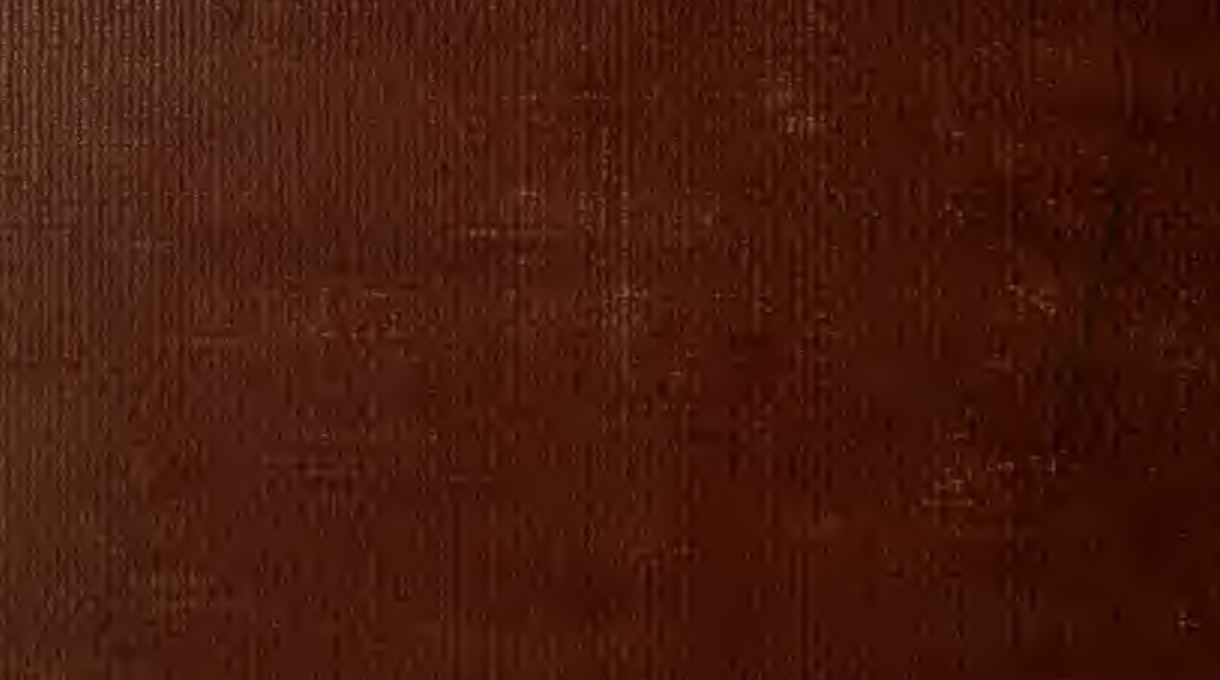